\title{
Fray Luis de León y la Historia*
}

\section{Actitud fundamental: sus manifestaciones}

Pacheco atribuye a fray Luis las más variadas, algunas de ellas extrañas, destrezas y saberes, desde pintura o astrologia, hasta matemáticas y teología, aparte del conocimiento de lenguaje ${ }^{1}$. En cada uno de los detalles del retrato seguramente hay algo de verdad. $\mathrm{Pe}-$ ro si hemos de juzgar por su obra, el hombre que en ésta aparece, aunque sensible para la naturaleza y curioso de artes y ciencias dispares, estaba interesado en el fondo por una sola cosa, siguiendo en ello a san Agustín, y esa sola cosa era "Dios y el alma". La obra de Dios en el mundo, cumpliéndose por la mediación de Cristo. De ahí que el tema central de sus escritos es, como hoy podríamos llamarlo, una "historia de la salvación".

Fray Luis no consagró obra ninguna a la historia, pero en todas se le ve a la escucha de los ejemplos y enseñanzas de la misma, sobre todo en cuanto ésta es historia sagrada ${ }^{2}$. Su fuente fundamental fue la Biblia, con predilección por el Antiguo Testamento. A esa escucha respondió mostrando minucioso interés por los detalles positivos de la narración, por captar la "letra"; pero aquello que

\footnotetext{
* Se citan las obras de Fray Luis por las ediciones siguientes: Obras completas castellanas. BAC. (Ed. Félix García, O.S.A.). Madrid, 1944, abreviadamente por Obras; con las siglas $C C, P C, N C, L J, P_{1}$, se corresponden respectivamente Cantar de los cantares, La perfecta casada, De los nombres de Cristo, Exposición del libro de Job, Poesías, Mag. Luysii Legionensis Augustiniani divinorum librorum primum apud Salmanticenses Interpretis Opera nunc primum ex mss eiusdem omnibus PP. Augustiniensium edita. Salmanticae, 1891-1895; 7 vols.; abreviatura: Opera. Para el Tratado de las leyes utilizamos De legibus. Ed. de Luciano Pereña, CSIC. Madrid, 1963. Con la sigla DI nos referimos a Colección de documentos inéditos para la Historia de España, tomos X-XI. Ed. de M. Salvá y P. Sáiz de Baranda. Madrid, 1847.

1. F. PACHECO, Libro de descripción de verdaderos retratos de ilustres $y$ memorables varones. Sevilla, 1599 .

2. Como muestra de su arte de historiar nos quedan las páginas inacabadas De la vida, muerte, virtudes y milagros de la santa Madre Teresa de Jesús, libro primero por el maestro fray Luis de León: Obras, 1365-1376. Fuera de esto, la erudición histórica que dejan traslucir sus escritos es notable, sobre todo por
} 
ante todo le atraía era la escondida significación o el "espiritu" 3 . De esa preocupación interpretativa sí que ha dejado constancia en sus libros. Constancia, primero, de actitud difusa que impregna todas sus páginas y, segundo, de expresa toma de conciencia del sentido de los acontecimientos y juicio reflejo sobre ese sentido. No tiene, pues, nada de forzado el intentar ordenar su pensamiento al respecto, ni resulta desmesurado, conforme vamos a ver, atribuirle una filosofía o, mejor, una teología de la historia.

Pero la cuestión, al menos de entrada, no resulta sencilla. En efecto, ante lo histórico la actitud de fray Luis es doble. Dualidad que hasta parece conducir a un dualismo de posiciones contrapuestas, si bien podremos llegar a entenderlas como complementarias. En la primera de esas posiciones vemos manifestarse una actitud negativa hacia lo histórico, y una actitud afirmativa en la segunda; cada una, incluso, en forma altamente depurada.

En vista de ello, formularíamos el tema que nos proponemos desarrollar en estas dos proposiciones:

1) Fray Luis de León entiende la historia como un proceso de decadencia y corrupción, de deterioro y vejez, a partir de unos origenes de plenitud, que, echados en olvido por el hombre, aparecen como ideal que rescatar y cuya imitación se presenta como normativa.

2) Fray Luis de León entiende la historia como un orden en desarrollo creciente y creativo según los designios de Dios, en los que, por edades, va cumpliéndose un plan providencial, salvador que tiene por eje a Cristo, y encuentra cumplimiento conforme el mundo y en particular el hombre se incorporan a $\mathrm{El}$, fructificando en la virtud que deriva de su gracia, hasta la plenitud final que todo sea recapitulado en Cristo.

Según estas dos proposiciones, en la primera de ellas se representa el ideal en el recuerdo de un bien perdido. La historia se entiende en función de un modelo arqueológico. La imagen en cuestión

lo que hace a la historia de Israel y de la Iglesia, así como a la del pensamiento, desde luego el teológico cristiano, pero también el filosófico pagano.

3. En un pasaje de NC confiesa: "Siempre fue flaca defensa asirse a la letra, cuando la razón evidente descubre el verdadero sentido": "Brazo de Dios" 534). Prácticamente toda su obra castellana y buena parte de latina consiste en comentarios bíblicos; y dice al respecto: "La cual escritura es útil de muchas maneras; porque no sólo es historia, sino doctrina y profecia". En el ejemplo de Job se nos informa sobre los azotes que sufrió y la paciencia en sufrirlos; pero el relato también "nos compone las costumbres y nos profetiza algunos misterios 
descansa en una actitud negativa frente a los tiempos históricos concretos, en los que los hombres se afanan a bulto por llevar adelante sus empresas, alejados de la fuente original de la naturaleza. La edad dorada se coloca en los orígenes, viéndose en lo que ha venido después una creciente pérdida del sabio concierto allí reinante, hasta llegar al duro y desorientado desconcierto de nuestra presente edad de hierro.

En la segunda de las proposiciones se entiende y representa la historia en función de un modelo escatológico. Los tiempos histórị cos concretos no serían menos lamentables tomados según la letra de su apariencia exterior. Pero interpretados según el espíritu, dejan entrever un discurso interior cumpliéndose en enriquecimiento sucesivo hasta culminar en nueva edad dorada que ahora tendrá su puesto en los fines. Por ocultos caminos todo irá colaborando para hacer que esos fines tengan realidad.

Habría que completar, pues, las dos proposiciones antes enunciadas con esta otra:

3) La historia exterior que llena los afanes de los hombres anda desorientada de acá para allá, salvo que se la entienda a la luz de los orígenes puros o se interprete su significación dentro del discurso salvador que lleva todas las cosas a su plenitud.

Según esta última proposición la historia externa se identifica con la vejez del mundo, que ha de regenerarse, bien a imitación de lo que fue puro en su nacimiento, bien participando en un renacimiento que instituirá esa pureza al final. Nacimiento y renacimiento constituyen la historia interna alejada del desconcierto y reco-

venideros": (LJ, "Dedicatoria", 849). En la exposición del Cantar, bajo los "requiebros" que se cruzan entre "Salomón y su esposa, la hija del rey de Egipto", se encubre la "Encarnación de Cristo y el entrañable amor que siempre tuvo a su Iglesia, con otros misterios de gran secreto y de gran peso": (CC, "Prólogo", 27). En la $P C$ dice que en el "último capítulo de los Proverbios", elegido para su exposición; "se pinta acabadamente una virtuosa casada con todos sus colores y partes, lo que puede conșiderarse historia; pero además, bajo la letra, se aprecian dos cosas: "lo uno, instruye y ordena las costumbres; lo otro, profetiza misterios secretos": ( $P C$, "Introducción", 210 y 218). A este respecto puede escribir Vossler: "Los textos que dedicó especialmente su atención... pertenecen, en parte, a los libros proféticos, $y$, en parte, a los escritos dogmáticos de la Biblia, pero ninguno de ellos a los puramente históricos, lo que es muestra de que veía su principal misión interpretar el sentido del texto en aquellos escritos en que habia de contar con una significación que excedía los límites de la interpretación literal y en la que debía procederse a descubrir los significados internos, ocultos, alegóricos, morales, anagógicos, etc.": C. VOSSLER, Fray Luis de León. Trad. de Carlos Clavería. (Buenos Aires 1946) 45. 
brada para el orden, la armonía y la paz. Ese ideal se encuentra en lo que fue $a b$ initio o en lo que será in novissimis.

Ordenaremos el desarrollo siguiendo los pasos de esas tres proposiciones.

\section{La vejez de los tiempos y la bondad de los orígenes}

Mircea Eliade, ordenando el material descriptivo recogido por etnógrafos e historiadores sobre la mentalidad primitiva o arcaica, hace notar cómo para ella las cosas del mundo y las realizaciones humanas "no tienen valor intrínseco autónomo". Los objetos de la naturaleza y los actos del hombre son "receptáculo de una fuerza extraña que los diferencia de su medio y les confiere sentido y valor". Esa fuerza es una realidad trascendente, primordial y arquetípica. Participando en ella o en comunión con ella toman consistencia las cosas. La vida puede parecer que discurre en el tiempo ordinario ajena a ese manantial animador. Pero la mente primitiva sabe que no es asi. En razón de lo cual sus invenciones culturales se ven empapadas de una práctica y un ritual enderezados a recordar esa convicción fundamental. En esas prácticas se vuelve a las fuentes, imitando las acciones que dioses o héroes hicieron al principio y de las que deriva el orden del mundo, repitiendo ritualmente esos actos, consistiendo en ello la sustancia del ceremonial de sus fiestas. Lo arquetípico es conservado como la razón que de una vez por todas desde los origenes explica la normativa de la existencia. Repetitivamente se vuelve a ello, recobrándose de la erosión de los tiempos para reinstalarse en lo que in illo tempore fue ejemplo para todos los tiempos 4 .

La regeneración periódica así escenificada y vivida tiende a la abolición del tiempo histórico. La mentalidad primitiva se resiste a abandonarse a la historia y lo que ésta tienen de irreversibilidad. Se defiende contra ella como contra algo que lleva dentro la amenaza de la disolución y decaída irrecuperable en el caos anterior al ordenamiento "creador". Prevalece de este modo un conservadurismo tradicional vuelto hacia los bienes del paraíso de los comienzos, entendiéndose la salida de él, confiando en el esfuerzo privado, en la acción personal o la gesta histórica, como desmesura llena de amenazas y por lo mismo pecaminosa.

4. M. ELIADE, El mito del eterno retorno. Trad. de Ricardo Anaya. (Buenos Aires 1952) 94-95; 99; 107; 126; 132; 137; 139; ID., Mitos, sueños y misterios (Buenos Aires 1961) 75-77; ID., Aspects du mythe (Paris 1963) 33-35. 
En suma el sentido para la historia y la asunción de su proceso como discurso abierto e irreversible pertenece a experiencias tardíamente asimiladas por la conciencia humana. Sólo desde fechas recientes ha entrado a conformar la mente del hombre, encontrándose esa mentalidad histórica en periodos anteriores más bien como fenómeno excepcional. Entonces y ahora no sin que, junto con la conciencia histórica, se den estructuras anímicas que reaccionan según el viejo modelo de lo arquetípico original.

Por lo que hace a la conciencia cristiana hoy nos resulta un lugar común remitir a la Biblia para ver en el Antiguo Testamento una visión del mundo de textura histórica, donde la realidad se define por referencia a la intervención de Dios en el tiempo, y donde la verdad no se entiende a partir de la consistencia de lo que es, sino en función de un sentido en devenir. Cuando el cristiano hace de Jesús de Nazareth un hecho histórico- la verdad, esto resultaba ininteligible para el esencialismo de la verdad de la mente griega. Pero estaba en contradicción igualmente con el modo de reacción de la mente arcaica, ya que una "plenitud de los tiempos" en el tiempo tenía que ser absolutamente ajena a mentes que, ante la ejemplaridad de los orígenes, dejaba en suspenso y como neutralizados todos los tiempos.

Ello no impedirá, sin embargo, ver cómo el arquetipo de los orígenes es operativo dentro del contexto bíblico. Lo que explica que también para los cristianos adquiriera un valor, en ocasiones hasta preponderante. Alli donde ha dominado una visión científica de la realidad, igual que cuando esa visión era metafísica, la tendencia fue la de minimizar la historia. La conciencia contemporánea parece haber roto con los órdenes fijistas y ahistóricos de entender la realidad. Aunque, por vocación, la ciencia tiende a organizarse en sistemas cerrados que dejan al mundo "libre de sorpresas" y reducen las novedades proféticas a predictibilidades lógicas. Si llegara un tiempo en el que el régimen de la ciencia alcanzara la madurez de big science, que después de todo ya hoy pretende dominar la visión de la realidad, ello significaría el fin de los tiempos, relegando a una forma de edad arcaica esta en que todavía hoy vivimos que sostiene como creencia firme la abierta y creativa irreversivilidad de la historia.

El propio Eliade, después de reconocer que la historia es la forma misma de entender el universo para el hombre occidental del presente, aventura la posibilidad de una edad poshistórica. La posición que define al hombre como "ser histórico", dice, "no ha con- 
quistado definitivamente el pensamiento contemporáneo" s. Hegel creyó que es en el reino de la naturaleza donde tiene aplicación el dicho de que "no hay nada nuevo bajo el sol", que en ella todo es repetitivo. La historia en cambio está abierta de continuo a la: novedad y a la sorpresa. Es el reino de la libertad y en ella nada se repite ${ }^{6}$. Pero, si en el pasado se nos muestra la humanidad oponiéndose por todos los medios a la historia, ciertas direcciones del propio pensamiento moderno y contemporáneo vuelven a coincidir con aquella vieja mentalidad, al revalorizar la periodicidad cíclica y el eterno retorno. Ejemplo de esto último puede ofrecerlo Nietzsche. En consecuencia Eliade concluye: "No está vedado concebir una época no muy lejana en que la humanidad, para asegurarse la supervivencia, se vea obligada a dejar 'seguir' haciendo la 'historia'..., y se conforme con 'repetir' los hechos arquetípicos prescritos y se esfuerce por 'olvidar', como insignificante y peligroso, todo hecho espontáneo que amenazara con tener consecuencias 'históricas'"?. Ciertas prospectivas futurológicas nos ponen ante el caso en el que se daría cumplida esa eventualidad. El propósito que anima a algunos científicos se encamina a que se cumpla, pensando precisamente que sólo entonces el hombre habrá alcanzado la madurez de sus posibilidades.

Si estas observaciones tienen lugar aquí es porque pueden permitirnos comprender cómo una misma persona, en el caso fray Luis, y ello como cristiano, puede buscar sentido a la vida orientándose sobre modelos interpretativos que parecen contrapuestos. Un hombre que, como él, creía en la creación, y no había pasado por la experiencia a que nos han acostumbrado las posteriores teorias de la evolución, tenía que ver en los principios arquetipos de lo perfecto. Cuando contempla las maravillas de la naturaleza - "cuando contemplo el cielo" - se siente cercano al "bien divino". Una verdadera edad dorada, un paraíso, se dio en el principio. Todas las cosas que vienen de ese principio, y en la medida en que conservan su original perfección, son modélicas. En cambio, por la perversión de la voluntad humana, se introdujo luego la corrupción. El avance en el tiempo coincide con la vetustez. El suelo del hombre que le rodea lo ve "en sueños y en olvido sepultado". De modo que el bien de la vida exige recuperar la plenitud dada en los origenes.

5. M. ELIADE, El mito, 168.

6. M. ELIADE, $E l$ mito, 100.

7. M. ELIADE, $E l$ mito, 169 ; cf. K. JASPERS, Origen y meta de la historia. Trad. de Fernando Vela. (Madrid 1968) 76.

8. $P$, "Noche serena", 1471-1472. 
Otra cuestión será la de ver si Dios creador, ante la obra perfecta salida de sus manos y después decaída, no ha providenciado un remedio salvador, una recreación, en la cual el hombre tendrá que participar, sumando su voluntad a los designios divinos, para que al fin los bienes del principio queden restituidos. Esta segunda línea de visión le permitirá disponer los acontecimientos en orden progresivo. De modo que lo que en un caso media su plenitud haciendo "memoria" de lo perdido en el otro la mida por la "esperanza" en lo llamado a alcanzarse. Estas dos perspectivas no eran antitéticas, como no podían serlo creación y redención. Lo que no impide que fray Luis adopte en casos ya una de ellas ya la otra. La unión se verificará en la historia de Dios, la historia de la salvación, que corre a otro plano que la historia de los hombres. Cuando esta última se toma como discurso autónomo es cuando no ve en ella más que decadencia y decrepitud, acomodándose entonces a una óptica que viene a coincidir con la profana tal y como por ejemplo era ejercida por los sabios y filósofos paganos. Para todos ellos era algo inconcuso pensar que "cualquier tiempo pasado fue mejor", y, en esta suposición periodizaban el tiempo, partiendo de la edad feliz en los comienzos hasta la calamitosa del presente. Cuando se prometía una nueva esperanza para el futuro era concebida como renacimiento de todo lo que fue glorioso en los orígenes. No otro es el sentido de la égloga IV de Virgilio cantando los tiempos de Augusto, como renovado orden naciendo del fondo de los siglos. De forma que todo el bien del hombre radicaba en restituir en su potencia y pureza lo primitivo. Ya hemos dicho que a ello tendían los rituales festivos de los distintos pueblos.

Analizando Popper la imagen de la ciudad ideal que Platón pinta en su República puede decir que se trata de una descripción "asombrosamente verídica, aunque un tanto idealizada, en la que se reconstruye la primitiva sociedad griega, tribal y colectivista, semejante a la de Esparta" ". El matiz peyorativo que encierran esos términos de "tribal y colectivista" se debe a los conocimientos etnográficos positivos que Popper tiene, pero que no corresponde a lo que Platón tenía realmente en la cabeza. Lo que sí. en cambio, tenía en ella era la imagen de una humanidad que conoció un antiguo esplendor y que con el curso del tiempo había decaído. El propio Eliade habla de una ontología correspondiente a la mentalidad primitiva, afirmando que era de "estructura platónica", y que "Platón podría ser considerado como el filósofo por excelencia de la

9. K. R. POPPER, The open society and its enemies, I (Londres 1974) 84. 
mentalidad primitiva; o sea como el pensador que consiguió valorar filosóficamente los modos de existencia y de comportamiento de la humanidad arcaica" 10 .

Enumeramos algunos de los lugares en que fray Luis adopta esa disposición rememorativa de un pasado mejor, de lo inmemorial.

1) La historia exterior de la Iglesia ha venido a menos, y, aunque Dios la asiste y su gracia no envejece, sí parecen viejos los hombres llamados a vivirla, encontrándose el modelo de su fuerza en los orígenes. Refiriéndose a santa Teresa y ante la inusitada manifestación de Dios a su alma escribe: "Y en esta vejez de la Iglesia tuvo por bien demostrarnos que no se envejece su gracia, ni es ahora menos la virtud de su espíritu que fue en los primeros y felices tiempos de ella; pues con medios más flacos en linaje que entonces, hace lo mismo, o casi lo mismo, que entonces" ". En la oda "A todos los santos" canta la virtud de los antiguos seguidores de Cristo, presentándole a El como modelo: María, la Magdalena, Agustín, Jerónimo... Parece tener que detenerse en los Padres de la Iglesia, no encontrando después a otra figura digna de recuerdo más que a Francisco.

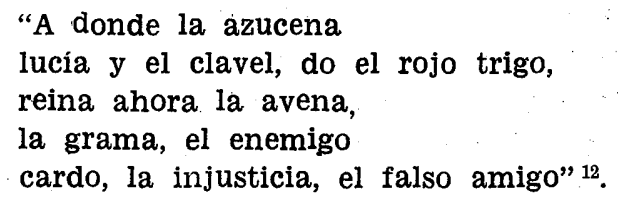

Pide a Dios que vuelva sus ojos con piedad, arranque tanto mal, y plante "aquello antiguo, santo y llano" ${ }^{13}$

10. M. ELIADE, El mito, 46. La concepción del cambio histórico como sucesivo deterioro al correr del tiempo fue mantenida por otras culturas distintas de la griega, representándose los orígenes como "edad de oro" o tiempo paradisiaco, así en las tradiciones hindúes, iranias, babilónicas, sin excluir la helénica. Ese motivo tiene un amplio eco en los autores greco-latinos, desde Platón, El político, 269 c-270, hasta Séneca (Cartas a Lucilio, XC); cf." H. EIBL, Metaphysik und Geschichte. Berlín, 1913; J. THYSSEN, Historia de la filosofía de la historia. Trad. de Federico Korell. Buenos Aires, 1954. Este último autor advierte, no obstante, que, junto con esa concepción idealizadora de los estadios primitivos, se da aquella otra que se orienta hacia una "teoría positiva del progreso", lo que para el período clásico ocurre con los atomistas y epicúreos, citando el ejemplo de Lucrecio Caro (De rerum natura, V, v. 911-913); cf. J. THYSSEN, Metaphysik, 15-21; M. ELIADE, El mito, 135-139.

11. "Carta dedicatoria a las Madres Priora Ana de Jesús y religiosas carmelitas descalzas del monasterio de Madrid": Obras, 1350.

12. $P$, "A todos los Santos", 1488.

13. $P$, "A todos los Santos", 1488. En la ed. que seguimos ese verso se lee: "Y planta aquello antiguo, humilde y llano", siguiendo aquí el texto que se recoge en Poesías. Ed. Losada, S. A. (Buenos Aires 1953) 67. 
En la "dedicatoria" a su opus magnum, De los nombres de Cristo, hace un juicio nada halagüeño de los tiempos que vive la Iglesia, en los que - se refiere al uso y trato con la Sagrada Escrituraa la gente le resulta "ponzoña lo que le solía ser medicina y remedio". Ello ocurre en el pueblo común por ignorancia y en los maestros por soberbia y presunción. En estos últimos ocurre que por el gusto en cuatro novedades, se sienten contentos e hinchados: "tienen título de maestros teólogos y no tienen teologia" ${ }^{\text {it. }}$

En la autodefensa que hizo ante la Inquisición, estando preso, se defendió con vigor de los que le acusaban de introducir nuevas doctrinas, alegando que en eso era precisamente en lo que pecaban sus oponentes, mientras que él siempre había manifestado su gran estima por lo antiguo. Muy consciente de que si el principio 0 lo más inmediato de la teología "son las cuestiones de escuela, y el crecimiento de la doctrina que escriben los santos", es en cambio, "el colmo y perfección y lo más alto de ella las Letras Sagradas, a cuyo entendimiento todo lo demás, como a fin necesario, se ordena" ${ }^{15}$. Por lo que no duda en arremeter contra "la condición triste de nuestro siglo", que no sólo no se muestra sensible para escuchar la lección antigua de la Escritura, sino que, sin rienda, se aplica a leer "mil libros, no solamente vanos, sino señaladamente dañosos", cosas que en la miseria de "nuestra edad" fascina a los indoctos con el beneplácito de los doctos. Algo muy distinto ocurría "en los primeros tiempos de la Iglesia", cuando su "gobierno era bueno", y el fruto respondía a la sementera, "como lo saben los que tienen alguna noticia de la historia de aquellos tiempos". He aquí sus palabras, un tanto apocalipticas, que no pueden ser más significativas: "De las calamidades de nuestro tiempo, que, como vemos, son muchas y muy graves, una es y no la menor de todas..., el haber venido los hombres a disposición que les sea ponzoña lo que les solía ser medicina y remedio; que es también claro indicio de que se les acerca su fin, y de que el mundo está vecino a la muerte, pues la halla en la vida" ${ }^{16}$.

14. NC, I, "Dedicatoria", 382. Entre sus obras se conserva un panegírico pronunciado ante el Claustro universitario en honor de san Agustín en el que contrapone la inteligencia a la estulticia, cargando los colores en la antítesis, e incluyendo en el número de los estultos a los propios maestros que, aunque cargados de títulos piensan y juzgan como los necios: "stultus est quisquis studiis atque iudiciis stultis similis est": Opera, VII, 337; LJ, IV, 6, 893; XV, 5, 1019; cf. L. G. ALONSO GETINO, Vida:y procesos del Maestro Fr. Luis de León (Salamanca 1907) 101-105.

15. NC, I, "Dedicatoria", 382.

16. NC, I, "Dedicatoria", 380-381. 
Lo que fue útil en aquel tiempo, en la "condición" triste de nuestros siglos se convierte en daño (que "anden en lengua vulgares" las Sagradas Escrituras). Las causas, para fray Luis son dos: "ignorancia y soberbia, y más soberbia que ignorancia; en los cuales males ha venido a dar poco a poco el pueblo cristiano, decayendo de su primera virtud" ${ }^{17}$.

2) Tampoco la historia presente de su patria le seduce. Las costumbres de la sociedad las ve dominadas por el artificio, la ambición y la entrega a empresas alocadas. Del gobierno de los poderosos ve ausente la justicia. Respecto a la propia gestión política del rey Felipe II se encuentran en él reticencias y censuras ${ }^{18}$.

Su poema "A Santiago" es una especie de visión global de la suerte y destino de España. Cierto que, ante el poderio de la nación imperando sobre el mundo, admite:

"Y de la gloria estamos en la cumbre".

Mas recuerda "del godo la potencia", aunque su cetro le fue arrebatado. "La espaciosa y triste España" cae en manos del "africano fiero" y es sometida a "bárbara condena". Confía en Santiago para que "cobre el español su bravo pecho", invitándole a repetir lo que, como ejemplo, se manifestó en los principios ${ }^{19}$.

3) Pero es como ascesis personal y enseñanza a todos los hombres como, ante la miseria de la vida, y mayor en aquellos que buscan remediarla con industrias y ambiciones, amonesta:

"El alma, que en olvido está sumida, torna a cobrar el tino

y memoria perdida

de su origen primero esclarecida".

Vuelve en sí el alma al desenredarse, en alas de la música, de cuanto "el vulgo vil adora", y remontar a la región

17. NC, I, "Dedicatoria", 379. Fray Luis que, por una parte, se extasiaba ante la visión armoniosa del universo $\mathrm{y}$, con ánimo renacentista, subrayaba la fuerza de la vida y la belleza de los mundos, por otra, derrama pesimismo cuando describe las historias de los hombres. En su hipotético discurso de Dueñas ante el Capítulo de la Provincia agustiniana a la que pertenecía, no se ve por parte alguna más que relajación en los súbditos y arribismo en los prelados. Al final de su comentario In Cantica ofrece una imagen deplorable de la piedad en la Iglesia: "Videmus pietate eliminata et omni antiquo more et disciplina deletis...": Opera, II, 461

18. Véanse, entre otros lugares: $C C, \mathrm{~V}, 113$; NC, "Pastor", 457; "Brazo de Dios", 545; LJ, XXXIV, 1228; cf. A. F. G. BELL, Luis de León. Un estudio del Renacimiento español (Barcelona 1927) 112-115.

19. $P$, "A Santiago", 1481-1485. 
"do no perecerá

música, que es la fuente y la primera" ${ }^{20}$.

En el nombre "Principe de la paz", que ha sido llamado "el mejor comentario a la oda a Salinas", escribe fray Luis que, a la vista del concierto de los astros en la noche, "imagen perfecta de la paz", el alma "como en una cierta manera se recuerda de su primer origen" ${ }^{2}$.

Entre tanto vive el hombre "entregado al sueño, sepultada esta tierra en "sueños" y "olvido". El olvido, la pérdida, el oscurecimiento y no cuidado afectan al "bien divino" para los que no hacen memoria de la primitiva y natural condición de lo creado ${ }^{22}$.

De modo que lo modélico se da en los orígenes. A ello torna el hombre para recobrarse del olvido y esclarecer su suerte.

A este respecto, sobre todo su obra poética, representa el reiterado ejercicio espiritual intimando al alma para que vuelva a sus principios y se nutra de lo arquetípico: del gran espectáculo siempre igual de la naturaleza o de los ejemplos no adulterados de "lo antiguo, santo y llano".

"Vida retirada", "campo deleitoso", "ocio santo", "pobre mesa y casa", "noche serena", "campos verdaderos", huerto plantado "del monte en la ladera", "fontana pura...": esas son las realidades a las que es insensible el hombre olvidado del "bien divino".

"El hombre está entregado

al sueño, de su suerte no cuidado" ${ }^{23}$.

"La fineza del sentir es del campo y de la soledad" ${ }^{24}$. En todas esas cosas sencillas, primitivas, naturales, verdaderas..., se le brinda al alma lo que en el fondo de ella se conserva de verdad, sencillez y pureza no adulteradas.

4) En las enseñanzas contenidas en su obra tienen un relieve notable aquéllas que, de una manera genérica y que habria que precisar, inducen à una "vuelta a la naturaleza", para guiarse por sus indicaciones y responder a su voz. Entendiendo por naturaleza el no corrompido estado primero de las cosas humanas, o lo que hay en el hombre de más profundo, escondido y alejado de las adulte-

\footnotetext{
20. $P$, A Francisco Salinas", 1458-1459.

21. NC, "Príncipe de la paz", 598.

22. $P, 1460 ; 1472$.

23. $P, 1472$.

24. NC, "Pastor", 449.
} 
raciones que ha venido introduciendo la curiosidad, el egoísmo o la soberbia. Esa vuelta a la naturaleza no significará dejación de los compromisos reales planteados por la vida, sino restituirlos a su primera verdad. Ello implica restituir al propio hombre a su verdadera naturaleza en la que la razón y la voluntad mandan sobre los apetitos, $y$, por encima del orden de cosas que con engaño pone en marcha el viciado interés que mira a la tierra, se imponga el orden providencial establecido por el cielo. A base, pues, de una antropología deudora del pensamiento griego y cristiano anteriores, a muchos respectos distinta de la de Rousseau, puede encontrarse en fray Luis un discurso interpretativo de la vida funcionalmente rousoniano ${ }^{25}$.

\section{Algunas muestras de esas enseñanzas:}

a) Fray Luis tiene predilección por comunicarlas recurriendo a modelos, tomados predominantemente de la historia antigua, en especial de la Biblia, sus patriarcas íntegros y sus mujeres fuertes; entre los santos cristianos, hombres de la Iglesia primitiva. Así, el modelo del justo lo encuentra en Job, y el modelo de la virtud para el estado más natural que conocemos, como es el matrimonio, va a buscarlo al libro de los Proverbios, siendo su reflejo "la perfecta casada". Modelo de cristianos serán Pablo, Antonio o Agustín. Por encima de todos el modelo será Cristo, "porque en él se crearon, y

25. Cf. $P C, 317-318 ; 320-322$. La orientación antropológica interesada por descubrir en el hombre su ser y sus fuerzas primitivas, más allá de cuanto la sociedad, la cultura o la historia ha venido depositando sobre él, tema que Rousseau toca bajo el símil de la estatua de Glauco, desfigurada por el tiempo y las inclemencias atmosféricas, y que compara con las alteraciones que sufre el alma en el seno de la sociedad, no fue algo primitivo de este autor. Es un tópico de la Ilustración, cuyos antecedentes hay que buscar en los dos siglos anteriores. En el Renacimiento ese mismo interés explica la significación que ahí tuvo "el tema adámico", poniendo de relieve lo sencillo y natural (cf. J. A. MARAVALL, Estudios de Historia del pensamiento español, III, Madrid 1975, 217-218. Para Rousseau ver "Préface"' de Discour sur... l'origine de l'inégalité parmi les hommes...). Con motivo de las polémicas suscitadas en torno al descubrimiento de América se discutió la tesis que defendía el buen natural y el virtuoso vivir de los primitivos conquistados frente a los conquistadores desfigurados por las pasiones nacidas y alimentadas en la civilización. El ejemplo más conocido de esta actitud dentro de la polémica lo ofrece fray Bartolomé de las Casas. En diversos pasajes expresa Fray Luis sus reservas, y también censuras, ante las obras que se consideran ornamento de las repúblicas, como son instituciones, leyes, edificios..., descuidando el bueno y sencillo vivir, incluso atentando contra él. Por lo que hace a los nuevos mundos descubiertos, encuentra pasmoso el hecho, pero no pinta de rosa la vida y costumbres de sus pueblos: Opera, II, 450-453; III, 156-174. Sobre la tendencia "adámica" en fray Luis cf. M. BATAILLON, Erasmo y España. Estudios sobre la historia espiritual del siglo XVI, II (México 1950) 393. 
por él se reformaron y por razón de lo que de él contienen en sí, son dichosos sus hijos" ${ }^{26}$.

Dios, que "mira la verdad y los ánimos", "se ofende de la inhunidad y de la mentira, aunque se vista de celo santo". Esto último representaban los amigos de Job arguyendo con él. Mientras que el propio Job "siempre dijo verdad en sus palabras, y en el ánimo anduvo descubierto y sencillo" ${ }^{27}$.

Lo que fray Luis aprende de la Escritura en relación con la casada virtuosa es aquello que conviene a su estado, siendo el de matrimonio "el primero y más antiguo de todos los estados; y sabemos que es vivienda no inventada, después que nuestra naturaleza se corrompió por el pecado y fue condenada a la muerte, sino ordenada luego en el principio, cuando estaban los hombres enteros y bienaventuradamente perfectos en el paraiso" "28. Lo que quiere Dios de cada uno es que "seamos aquellos mismos que profesamos ser", y no admite en su casa "al que no hace el oficio en que se le pone". Este orden de estados viene de la naturaleza, como de la naturaleza viene el que la mujer sea mujer y haga aquello para lo que fue nacida, que es guardar la casa, servir al marido y parir y criar hijos, velando por la hacienda común y poniendo concierto de afectos en la familia. El retrato que hace de la mujer casada no cuadra demasiado con los aires de reivindicación que privan en nuestra sociedad; tampoco parecía estar la suya demasiado ajustada a su ideal, a juzgar por la acre censura que de ella hace en algunos de sus capítulos. Pero nuestro autor no se propone ser galante 0 adulador, sino verdadero. $\mathrm{Y}$ el ideal de esa verdad lo encuentra en las "buenas y antiguas costumbres". La "mujer de su casa", de su marido y de sus hijos, no tiene nada que ver con la "mujer de mundo" de época ninguna, sí en cambio imita o repite el modelo de mujer fuerte de la Escritura.

b) Sus ideas sobre la educación se inspiran en idénticos principios. En cuanto sus libros encierran, como en efecto ocurre, un interés pedagógico, caen en lo que llamaríamos una pedagogía de fuentes y de principios y no de derivativos, de títulos o de "pequeños gustos en ciertas cuestiones" que no van a la sustancia. La madre ha de criar al hijo y darle con su leche su buena condición. "La obligación que tiene por su oficio de hacerlos buenos, esa misma le

26. NC, "Hijo de Dios", 732.

27. $L J$, XLII, 1320.

28. PC, "Introducción", 208-209. 
pone en la necesidad a que los crie a sus pechos. Porque con la leche, no digo que se aprende, que eso fuera mejor porque contra lo mal aprendido es remedio el olvido, sino digo que se bebe y convierte en sustancia y como en naturaleza todo lo bueno y lo malo que hay en aquella de quien se recibe. Porque el cuerpo ternecito de un niño, y que salió como comenzado del vientre; la teta le acaba de hacer y formar. $\mathrm{Y}$ según quedare bien formado el cuerpo, así le avendrá el alma después, cuyas costumbres ordinariamente nacen de sus inclinaciones de él. Y si los hijos salen a los padres de quien nacen ¿cómo no saldrán a las amas con quien pacen, si es verdadero el refrán español?" "29: De modo que no piensen las casadas que "con parir un hijo de cuando en cuando, y con arrojarle luego lejos de sí en brazos de un ama, son cabales y perfectas mujeres" ${ }^{30}$.

Así pues la educación para ser buena ha de ir muy en consonancia con lo que el natural de las cosas pide.

Es también defectuosa la educación en las letras y en las ciencias, que se contenta con las convencionalidades y no se nutre de lo fontal y modélico. Fray Luis achaca a los "maestros teólogos" que lucen su saber en la Escuela el que se tengan por doctos, hinchados con cuatro novedades de los últimos que enseñaron, con su Soto y su Cano ${ }^{31}$, por ejemplo, y descuiden la sustancia de la vieja sabiduría contenida en la Escritura.

Por lo que hay en él de protesta contra lo que es uso tener por buena crianza, por erudición y doctrina; desarrolla en sus escritos una paideia o disciplina que pudiera llamarse subversiva o libertaria. Pero, dado que no se cansa de apoyarla en lo antiguo, buscando su inspiración en la fuente no contaminada de los origenes, su pensamiento puede parecer reaccionario, como ocurre en $L a$ perfecta casada, o, lo mismo que el de Platón, reflejo de la ontología de la mente arcaica. En la segunda parte se verá cómo esta actitud se dobla de la que puede considerarse su opuesta, y que es audazmente progresiva. De este tipo de pensamiento, en los dos aspectos, que tiende a pensar "holísticamente", calificado por Popper "historicismo", en el cual sin duda participa fray Luis, puede afirmarse:

"El hecho de presentar una idea tan venerable como audaz y revolucionaria descubre, creo yo, un conservaduris-

29. $P C$, XVII, 317-318.

30. $P C$, "Introducción", 208.

31. $D I, \mathrm{X}, 371$. 
mo inconsciente... Después de todo, ¿no serán los historicistas los que tienen miedo al cambio? ¿Y no será quizá este temor a cambiar lo que les hace tan absolutamente incapaces de reaccionar racionalmente ante la critica y lo que hace que los demás acojan tan bien sus enseñanzas? Ciertamente parece como si los historicistas estuviesen intentando compensar la pérdida de un mundo inmutable aferrándose a la creencia de que el cambio puede ser previsto porque está regido por una ley inmutable" ${ }^{32}$.

El "holismo", dice en otro lugar,

"lejos de representar un alto nivel o estado avanzado en el desarrollo del pensamiento, es característico de una edad pre-científica" ${ }^{33}$.

Sabido es que documentación de esta tesis es ofrecida por Popper en su obra La sociedad abierta a sus enemigos, enemigos que van desde Platón a Hegel y Marx ${ }^{34}$. Dejando de lado el juzgar esas afirmaciones, lo cierto es que fray Luis cae de lleno en el tipo de mentalidad por ellas caracterizado.

Quedarian muchos aspectos que subrayar confirmativos de la tendencia arcaizante manifiesta en su enseñanza. Consignemos sólo dos indicaciones más.

c) Confirma esa actitud su modo de entender el buen gobierno. Ni para el alma ni para la república es bueno el de fomentos externos, lavatorios, renuncias ascéticas o leyes puestas. Todas estas cosas serán convenientes y hasta necesarias, pero no conducen, por sí mismas, a la armonía ni a la paz. Hasta pueden ser dañosas. Así aquellas leyes que consisten en "escritura", que "tratar sólo con la ley escrita es como tratar con un hombre cabezudo por una parte y que no admite razón, y por otra poderoso para hacer lo que dice, que es trabajoso y fuerte caso". Se apoya en Platón para decir que no es la mejor gobernación la de leyes escritas. Sosteniendo en cambio que "la perfecta gobernación es de ley viva" ${ }^{35}$. Y esta ley es la que les viene a las cosas como de su natural, que es lo que expresamos cuando decimos "tener ley" a algo. Desarrolla estas ideas

32. K. R. POPPER, La miseria del historicisco. Trad. de Pedro Schwartz. (Madrid 1961) 176.

33. K. R. POPPER, La miseria del historicismo, 145.

34. K. R. POPPER, The open society... Lodres, 1974; 2 vols. Lia obra había aparecido en 1945.

35. NC, "Pastor", 457. 
en el nombre "Pastor", viendo en el pastor al símbolo y ejemplo del buen gobierno ${ }^{36}$.

"De manera que la vida de pastor es inocente y sosegada y deleitosa, y la condición de su estado es inclinada al amor, y su ejercicio es gobernar dando pasto, y acomodando su goblerno a las condiciones particulares de cada uno, y siendo él sólo para los que gobierna todo lo necesario, y enderezando siempre su obra a esto, que es hacer rebaño y grey" ${ }^{37}$.

El gobierno de Dios es perfecto porque "es gobernador de todo por su naturaleza y no por voluntad ajena". Por el contrario, "si los príncipes y regidores del mundo son en sus oficios muchas veces injustos es porque les es advenedizo y como extraño el oficio, porque ninguno por su naturaleza es rey, y todos lo son o por voluntad de los hombres o por su violencia. Mas si fuese uno tal que la naturaleza misma suya le pusiese en las manos las riendas y el gobierno de todo, en esa su gobernación sería su naturaleza, y por consiguiente seria la misma regla y razón de la justicia" ${ }^{38}$. Pero sólo Dios es asi. En las condiciones del mundo Jesucristo, aun considerado sólo como hombre, en virtud de la perfecta rectitud que el conviene, podría ser ese príncipe gobernante según razón y justicia en quien el gobernar sería su naturaleza ${ }^{39}$.

d) Confirma esa misma actitud su manera de entender el oficio de sabio, cuidando de las almas y dando lecciones de concierto y gobierno a los hombres. Aparecida la primera edición (1583) De los nombres de Cristo y La perfecta casada le censuran de unas y otras cosas, entre ellas de no escribir en latín sino en romance y de seguir su discurso en diálogos y no en forma de tratado, contra lo que parece pide el asunto teológico de que se ocupa, en el caso los Nombres de Cristo. Contesta: en su lengua "romance" escribieron los modelos antiguos que todos admiran. Platón, en griego; Cicerón, en latín; Basilio, Crisóstomo, Gregorio y Cirilo; "en su lengua materna griega". $Y$ lo hicieron con frecuencia en forma dialogada. De modo que hace lo contrario de lo que le piden los que se creen

36. Entre otros lugares, NC, "Príncipe de la paz", 613. Para el desarrollo de ese tema cf. S. ALVAREZ TURIENZO, "Ley y vida en el pensamiento moral de fray Luis de León": Religión y Cultura (1976) 123-163.

37. NC, "Pastor", 450.

38. $L J$, XXXIV, 1221-1222.

39. LJ, XXXIV, 1221-1222; NC, "Pastor", 457; De legibus. Ed. Luciano Pereña. (Madrid 1963) 77. 
a la última. Lo hace en lengua vulgar, aunque no de acuerdo con los que "piensan que hablar romance es hablar como se habla en el vulgo", sino sacando la lengua de su vulgaridad, "levantándola del decaimiento ordinario", y acercándola a los modelos, "siguiendo en ello el ejemplo de los escritores antiguos" ${ }^{40}$.

A los que le tachan de meterse a aconsejar casadas, como oficio impropio de fraile, sugiere si no será también oficio impropio del Espíritu Santo, cuya enseñanza en todo caso es la que él declara. Se pregunta también si no hicieron eso siempre los sabios. "Es propio del fraile sabio y del que enseña las leyes de Dios, con la especulación traer a luz lo que debe cada uno hacer, y decirselo; que es lo que yo allí hago y lo que hicieron muchos sabios y santos, cuyo ejemplo, que he tenido por blanco, asi en esto como en lo demás que me oponen puede conmigo más para seguir lo comenzado que para retraerme de ello aquestas imaginaciones y dichos" 4l.

Eso, por una parte, en cuanto a lo que toca a las formas externas o a los cometidos propios o impropios también externos a la sustancia de la doctrina. Algo que interesa a esa sustancia, y como presupuesto de lo que se enseña, tiene que ver con el vehículo de toda enseñanza que es el lenguaje y con el modo de entender lo que en él se manifiesta o expresa. El capítulo primero de los Nombres está dedicado a estudiar ese presupuesto.

Fray Luis nos dirá que el verdadero hablar restituye las palabras a su primer oficio de vecindad con las cosas, inmediato a ellas y como expresión de su ser más propio y de su naturaleza, oficio del que en el uso corriente las lenguas con frecuencia se han olvidado. Los nombres son, nos dice, sustitutos de lo que nombran. "Unos son [sus] imágenes por naturaleza, y otros por arte". "Los primeros son los nombres principalmente", están en el alma y "sustituyen por aquellas cosas cuya figura son por la semejanza natural" ${ }^{42}$. De estos nombres hay que decir que en su significación está aquello de donde "nacen". Tiene fray Luis por la "primera lengua" de todas la hebrea ${ }^{43}$, y entiende que los nombres puestos a las cosas por Dios mismo o por Adán inspirado por Dios, son allí el de cada cosa su propio nombre. Lo cual representa decir que "a cada una les venía como nacido aquel nombre" " Esto lo entiende Juliano como "guiar

40. NC, "Dedicatoria" al lib. III, $671 ; 674$

41. NC, "Dedicatoria" al lib. III, 675.

42. NC, "De los nombres en general", 394.

43. NC, "De los nombres en general", 393. "Quae omnium linguarum prima fuit", escribe fray Luis, citando a san Agustín (De civitate Dei XVI, 11) y a san Ambrosio (De vocatione gentium II, 4: Opera, V, 259).

44. $N C$, "De los nombres en general", 395. 
el agua muy desde su fuente" ${ }^{45}$. Y, en efecto, eso es lo que ocurre. Lo cual para nuestro próposito significa que el modelo de toda comunicación humana ha de buscarse en los orígenes, donde se encuentra el hablar arquetípico. Restaurar ese arquetipo será una de las tareas a que más concienzudamente se entrega nuestro autor, como lo demuestra con los hechos de: o.) valorar altamente el oficio de traductor; $\beta$ ) observar un rigor literal que aspire a la más rigurosa fidelidad en orden a rescatar el sentido originario; $\gamma$ ) la minucia con que se entrega a interpretar los sentidos que se esconden tras esos nombres primeros nacidos de las cosas y por tanto comunicativos de su verdad ${ }^{46}$.

e) Finalmente indiquemos algo que se desprende todo lo dicho, a saber el modo como entiende el "ideal del sabio". Ese ideal abarca todas las manifestaciones de la existencia. Para realizarle se exigirá siempre la misma dinámica. La salud del cuerpo no dependerá de cuidados melindrosos, sino del contacto con la naturaleza y de seguir sus indicaciones. Lo mismo ocurre con el vigor varonil y la gracia y hermosura femenina. Es el aire y el agua y no los afeites postizos el secreto del bienestar y el bienparecer. La dicha no se encuentra entre los cuidados, sino en la sencillez que se descarga de necesidades. La vida del campo es escuela de inocencia y verdad ${ }^{47}$. Quien busca la ciencia no la encontrará en el cortejo de novedades de que están hinchados los que se tienen por doctos, sino en los antiguos maestros. De la misma manera la teología no está encerrada en los sofisticados libros académicos sino en la abierta sencillez de la Escritura. El cristiano encontrará sus modelos de vida en la Iglesia primitiva y el que desee vivir en justicia lós tendrá en los apóstoles y santos antiguos. Vida ideal, en suma:

"La que huye el mundanal ruido

$y$ sigue la escondida

senda por donde han ido

los pocos sabios que en el mundo han sido" ${ }^{48}$.

En todos y cada uno de esos aspectos la plenitud modélica se encuentra en los principios. El hombre se ve invitado a hacer memoria de ella y a repetir su forma arquetípica expresada en los co-

\footnotetext{
45. $N C$, "De los nombres en general", 394.

46. CC, "Prólogo", 29-30; LJ, "Dedicatoria", 850.

47. $P C$, II, 230.

48. $P$, "Vida retirada", 1450.
} 
mienzos. Ello implica algo más que una metódica vuelta a las fuentes. Se trata de una vuelta real, que es una recuperación, a la naturaleza; de estar con el universo en su estado de plenitud naciente, descargándose de su lastre de descrepitud acumulada: recuperación del aevum y abandono del saeculum.

Hay un capitulo de doctrina en fray Luis que en cierto modo resume cuanto se ha dicho en los puntos anteriores, ofreciendo la que llamaríamos "forma de vida" ideal o más conforme a la naturaleza del hombre en su condición terrena. El habla, al efecto, de "maneras de vida" o de "viviendas". Esa forma de vida hace corresponder el "bien divino" de la virtud con la obligada ocupación y trata del hombre con las cosas de este mundo, mediante el trabajo, para dar satisfacción a sus necesidades. Nos ofrece con ello, cierto que no una interpretación materialista de la historia, pero sí una interpretación naturalista, en la que el orden de lo espiritual se entiende en consonancia con lo ordenado por la naturaleza, en la sencillez de su estado primitivo. Lo que se corresponde con las "viviendas" en cuestión es, de una parte, la forma de vida virtuosa y de otra la forma de vida económica.

Cierto que fray Luis no se interesa directamente por la ciencia económica, sino por la ciencia moral. Pero relaciona la forma de vida económica que se profesa con el hombre que se es. Su doctrina económica es rudimentaria; y aunque esto no interese al caso, resulta revelador, ya que en ella dista mucho de profesar las ideas que en su tiempo podrian haberse considerado avanzadas. Se inspira más bien en los autores clásicos y en último término en la $\mathrm{Bi}$ blia, sosteniendo que la agricultura es la "vivienda" más natural, conveniente y provechosa al hombre en todos los sentidos, no sólo el material, sino y sobre todo, el espiritual.

Los capítulos segundo y cuarto de $L a$ perfecta casada se dedican prácticamente a tratar esa cuestión. En el primero de esos lugares habla de dos maneras de hacer renta, sustentarse y vivir; una es de "la labranza del campo"; otra, "del trato o contratación con otros hombres". Y dice de la primera que es de "ganancia inocente y santa ganancia, porque es puramente natural". En la segunda entran "los mercaderes y los maestros y artífices de otros oficios que venden sus obras" con voluntad de sus dueños, y también que las venden sin voluntad, como acontece con el guerrero; y dice de esta renta o ganancia que "es poco natural, y adonde las más veces interviene alguna parte de injusticia y de fuerza". Por lo que,

"si vamos a la conciencia, vivir uno de su patrimonio es vida inocente $\mathrm{y}$ sin pecado, y los demás tratos por mara- 
villa carecen de él. Si al sosiego, el uno descansa en su casa; el otro lo más de la vida vive en los mesones y en los caminos. La riqueza del uno no ofende a nadie; la del otro es murmurada y aborrecida por todos. El uno come de la tierra, que jamás se cansa y enoja de comunicarnos sus bienes; al otro desámanle esos mismos que le enriquecen. Pues si miramos la honra, cierto es que no hay cosa ni más vil, ni más indigna del hombre, que el engañar y el mentir; y cierto es que, por maravilla hay trato de éstos que carezca de engaño...; y forzoso es que a quien trata de engañar que le engañen; y que a quien contrata y se comunica con gentes de ingenio y de costumbres diversas, se le peguen muchas malas costumbres. Mas al revés: la vida del campo y el labrar uno sus heredades es una como escuela de inocencia y verdad; porque cada uno aprende de aquellos con quien negocia y conversa. Y como la tierra en lo que se le encomienda es fiel, y en el no mudarse es estable, y clara y abierta en brotar afuera y sacar a luz sus riquezas, y para bien hacer liberal y abastecida, así parece que engendra e imprime en los pechos que la labran una bondad particular y una manera de condición sencilla, y un trato verdadero y fiel y lleno de entereza y de buenas y antiguas costumbres" ${ }^{49}$.

En este último pasaje habla de la disposición del cuerpo y del ánimo, de la institución de los hijos y del orden de la familia, y dice que "todo va por la misma manera", con inocencia en el campo y con engaños en el mercado, en la industria y en la guerra.

En el capítulo cuarto, una vez más, "toma el agua de su principio", y habla entonces de "tres maneras de vida", que "son las que se reparten y a las que se reducen todas las maneras de viviendas, que hay entre los que viven casados". Recuérdese que los asuntos económicos eran comúnmente tratados en la antigüedad como relacionados con la familia o la casa, de donde el nombre de "economía". Fray Luis añade aqui a los que "labran la tierra" y a los que "se mantienen de algún trato y oficio", lo que "arriendan sus haciendas a otros y viven ociosos del fruto de ellas". Explica que entre los primeros está no sólo el labrador que "con un par de bueyes labra su pegujar, sino también los que con muchas yuntas y con copiosa y gruesa familia rompen los campos y apacientan grandes

49. $P C$, II, $229-230$.

50. $P C$, IV, 239-241. 
ganados" ${ }^{51}$. Recordemos de paso que también la vida del pastor se nos describe como inocente, ordenada e inclinada a lo bueno ${ }^{51}$. La vida de contratación "abraza al tratante pobre y al mercader grueso, $\mathrm{y}$ al oficial mecánico, y al artifice, y al soldado y, finalmente, a cualquiera que vende su trabajo, o su arte o su ingenio". La tercera forma de vida, la "ociosa" es la que "el uso ha hecho propia ahora de los que se llaman nobles y caballeros y señores; los que tienen o renteros o vasallos, de donde sacan sus rentas".

Pues bien,

"si alguno nos preguntare cuál de estas tres vidas sea más perfecta y mejor vida, decimos que la de la labranza es la primera y la verdadera; y que las demás dos, por la parte que se avecinan con ella y en cuanto le parecen, son buenas; y según que de ella se desvían son peligrosas".

Analiza después los dos elementos que se dan en la agricultura, que son la ganancia y la ocupación. En cuanto a la ganancia "es inocente y natural..., sin agravio o disgusto ajeno". En cuanto a la ocupación "es loable y necesaria, y maestra de toda virtud". La segunda manera de vida es buena en cuanto da ocupación, y en eso coincide con la primera; pero en cuanto a la ganancia es peligrosa, ya que "pocas veces [se recoge] sin alguna mezcla de engaño". Por lo que hace a "la tercera y última vida", si bien en cuanto a la ganancia parece coincidir con la primera, al provenir de la tierra, dadas las mediaciones que sufre de arrendamientos y renteros, fácilmente engendra desigualdades. Fray Luis, no obstante la encuentra "ganancia y renta segura y honrada". Cosa distinta sucede de atender a la ocupación, puesto que el ocio de esa vida tercera la hace "ocasionada a daños y males gravísimos". "De manera que lo perfecto y lo natural, en esto de que vamos hablando, es el trato de la labranza" ${ }^{2}$.

No deja de ocurrirsele a fray Luis la obvia objeción de que su casada perfecta puede ser ejemplo de vida en el campo y entre labradores, pero "las señoras delicadas de ahora [dirán] que esta pintura es grosera". Responde:

"Esta casada es el dechado de todas las casadas, y la medida con quien, asi las de mayores como las de menores estados, se han de ajustar cuanto a cada una le fuere po-

51. NC, "Pastor", 450.

52. $P C$, IV, $239 ; 241 ;$ II, 227 ; LلJ, I, 3, 859, 
sible; y es como el padrón de esta virtud, al cual la que más se avecina es más perfecta. Y bastante prueba de ello es que el Espiritu Santo, que nos hizo y: nos conoce, queriendo enseñar a la casada su estado, la pinta de esta manera" s?.

No es necesario extenderse en mostrar cómo fray Luis sigue en lo expuesto los modelos clásicos, sobre todo el de los romanos, que con insistencia se ocuparon de re rustica, desde Catón, pasando por Columela hasta Plinio el Viejo. Cicerón resume el sentir romano cuando escribe: nihil melius, nihil homine libero dignius, quam agricultura $^{54}$. Lo que los romanos loaban en la res agricola era el ideal de vida de los primeros tiempos del Lacio asentado en las virtudes campesinas de que dieron prueba los patriarcas del pueblo, austeros e incorruptos, fieles al mos maiorum. Con un espiritu socializante ${ }^{55}$, que fray Luis no comparte, mostraron esa misma preferencia por la agricultura en Grecia sus más grandes filósofos, Platón y Aristóteles. Pero nos saca él mismo de dudas:

"Pudiera yo aqui ahora extender la pluma alabándola [la vida primera de trato con la labranza]; mas dejárelo, por no olvidar mi propósito y porque es negocio sentenciado ya por los sablos antiguos, y que ha pasado en cosa juzgada su sentencia".

Añade:

" $Y$ también porque a los que sabemos que Dios puso al hombre en esta vida, y no en otra, cuando le crió, $y$ antes que hubiese pecado y cuando más le regalaba y queria, bástenos esto para saber que de todas las maneras de vivir sobredichas es aquésta la más natural y la mejor" "60.

De modo que sobre el modelo de lo antiguo se mide cuanto de perfecto puede encontrarse en los estados del hombre al presente. Con lo antiguo "natural" se corresponde "lo mejor". "La más ilustre empresa de la vida", que es la virtud y que declara "hija del cielo" ${ }^{57}$, para su crianza ha de acompañarse de aquella "vivienda", que es la

53. PC, IV, 239.

54. CICERON, De officiis, I, 43 ; cf. R. CONNARD, Historia de las doctrinas económicas (Madrid 1961) 15-20.

55. R. CONNARD, Historia, 5-7; 15-19.

56. $P C, I V, 241$.

57. $P$, "A Don Pedro Portocarrero", 1453. 
más antigua, inocente y natural, a saber la labranza o el pastoreo. Vivienda "maestra de toda virtud". La pintura que del ideal de vida nos ofrece fray Luis resultará a esta luz no ya "grosera" sino reaccionaria. La línea seguida por el progreso humano, y que ha avanzado al paso del desarrollo del comercio y la industria, le resultaba repulsiva, signo de decadencia y patente de olvido de la dichosa edad de los principios. A este respecto, la actitud frailuisiana ante la historia refleja con notable exactitud la que habia quedado establecida como modélica por la mente clásica. En esa actitud se advierte más bien una voluntad que rechaza la historia y sus cambios, que ve en la irreversibilidad de los acontecimientos una latente amenaza a los bienes de la armonía y de la paz. Frente a la inocencia de los origenes, pregonada por la voz de la naturaleza, el "mundanal ruido" representa lo pecaminoso. La negativa al cambio que encubre esa actitud puede refiejarse en este imperativo que se repite a lo largo de la Perfecta casada: "Lo justo y natural es que cada uno sea aquello mismo para que es", en el que se da la versión romance del ideal platónico de justicia ${ }^{58}$, que consiste en que "cada uno se mantenga en su puesto" y "haga lo propio de él". Ideal consagrador del status quo. Sobre el significado inmovilista que comporta el ideal de orden justo, conservador y hasta reaccionario, en Platón se ha pronunciado más de una vez la crítica ${ }^{59}$. Platón asociaba cambio con deterioro. Su filosofía neutraliza el movimiento y es refractaria a la historia.

Fray Luis pudo creer, en momentos de su vida, que su fe cristiana daba la razón a esa filosofía. Se hace coincidir el paso del tiempo con la decrepitud del mundo, idea autorizada en textos agustinianos. La doctrina de la creación, entendida a la letra, obligaba a ver el mundo en su plenitud de bien y de armonía en los principios, recién salido de las manos de Dios. La corrupción vino después, inducida por la perversión del hombre. Ante esas descripciones pesimistas de las costumbres de su tiempo no acierta uno a ver cómo pueden conjugarse con la obra de la redención. Presente de continuo la acción redentora en el mundo, si con el nacimiento de Cristo llegan los tiempos a su plenitud, fray Luis habla a veces como si la fuerza recreadora de Cristo se hubiera agotado en la Iglesia primitiva, iniciándose posteriormente un nuevo período de decrepitud siempre in crescendo. Acá y allá se perciben algunos indicios de esa fuerza, pero manifestándose en pocos selectos, con-

58. III, 236; PLATON, Repriblica, 433 b; 430 c; 432 c.

59. Recuérdense los lugares citados de Eliade y de Popper. 
certados los más para ir de mal en peor. Esquemas clásicos tomados de los sabios del helenismo parecen servirle de modelo para establecer sus juicios.

\section{Intermedio: Sobre el cambio de signo en la interpretación}

No obstante, en el fondo, el sentir cristiano trabajaba en otra dirección. Y lo que en fray Luis había de más personal era sensible a esos motivos, que serán los que terminan imponiéndose, organizándose en torno a ellos lo más sustancial de su obra.

Parecen superponerse, pues, en sus concepciones dos modelos explicativos insolidarios entre sí. Los dos sin embargo venían mezclados en la tradición doctrinal cristiana, conjugando su operatividad en la vida.

Según el primero de esos modelos la historia se presentaba como un teatro de desconciertos. En algún tiempo primero sé dio la armonía. En los sabios se hacía memoria de los dorados comienzos que la gente común tenía en olvido. La enseñanza de esos sabios invitaba más que a renacer, a recobrarse y, negando el maleficio corrupto engendrado por el paso del tiempo, restaurar el bien de los principios. La gesta de Ulises por un mundo lleno de peligros, seducciones engañosas, pasiones y males, volviendo, como a final dichoso a su patria da la medida del ideal de la vida griego.

Para el segundo de esos modelos, en cambio, cada tiempo trae un aviso de nacimiento. El mundo se rejuvenece al impulso de un bien que es "buena nueva", donde lo nuevo y lo futuro son promesas de la ansiada edad de plenitud. Será entonces la historia vehículo de esa plenitud, de modo que no pueda disociarse de ella la esperanza de salvación.

No puede decirse que fray Luis abandone claramente la primera de las perspectivas señaladas. Pero con el paso del tiempo adquiere predominio la segunda. Si aquella continúa presente en su obra madura puede decirse que ello ocurre como apoyatura convencional y a modo de recurso literario, pero sin que dé forma a su pensamiento. La idea de la historia según el segundo de los modelos mencionados, nunca ausente de sus páginas, y aquí y allá insinuada, llega a ser con el tiempo definidamente tematizada. Hasta puede decirse que fue su tema único, como lo veremos al examinar su interpretación del Cantar de los cantares.

Hay en relación con esto un problema relativo al discurso genético y de maduración del espíritu de fray Luis. El examen de su obra es sospechoso al respecto, una vez que toda ella es posterior 
al momento que estimamos crucial en esa evolución, y que situamos en sus años de cárcel. No es momento de tratar con detalle esta cuestión, aunque no renunciamos a hacerlo en otro lugar. Tuvo fray Luis en la prisión mucho tiempo para reflexionar. Lo que le ocurrió y las razones por las que le ocurrió debieron darle que pensar. $Y$ probablemente dio en pensar que en efecto estaba allí encerrado por albergar un espíritu disidente, respecto al cual no estaba en claro consigo mismo, pero que le llevó a imprudencias, incluso a temeridades. Lo que entonces hizo fue caer en la cuenta, mas no para afirmarse en la disidencia, sino para, con pleno conocimiento de causa, saber gobernarla. El examen cuidadoso de los documentos del proceso pueden aclarar en buena parte esta cuestión.

Personalmente pienso que fray Luis sale otro de la prisión. Maduro en sus ideas y sobre todo en su alma; por ello seguro de sí mismo. Insinúa él mismo ese cambio en páginas escritas en la cárcel en aquel "ocio - dice - en que la injuria y mala voluntad de algunas personas me han puesto". Los trabajos, añade, "han serenado mi alma con tanta paz, que no sólo en la enmienda de mis costumbres, sino también en el negocio y conocimiento de la verdad veo ahora y puedo hacer lo que antes no hacía" ${ }^{60}$.

El P. Getino, nada dispuesto a repartir bondades en la vida y andanzas de nuestro vate, acierta cuando dice que, tras su "vida asendereada", al final de su camino, "en las aspiraciones y gustos del Maestro se había operado un cambio radical". Recuerda también su "resistencia a volver a encargarse de la anhelada clase", anhelada si se tiene en cuenta los trabajos que se tomó luchando por obtenerla ${ }^{61}$. El cambio a que se refiere significa que, "serenado ya el cielo de su espíritu, aquel varón insigne dulcificó considerablemente el trato y mereció por sus virtudes que los agustinos de la floreciente Provincia de Castilla le eligiesen Prelado y toda ella", y que, "en ese puesto, respetado y querido de los suyos, y admirado de los extraños, dejó esta vida, cuando era más deseada y necesaria" ${ }^{62}$.

Por el contexto del propio capítulo en que se consignan esas frases puede colegirse que están dichas no tanto para dejar constancia de la virtud de fray Luis, si bien sólo cuando es alcanzado por los desengaños de la vida, sino de la magnánima imparcialidad del propio biógrafo. Pero dejemos esta cuestión. Lo que no nos dice el padre Getino es dónde, cómo y por qué se operó ese "cambio

60. NC, "Dedicatoria" al lib. I, 384.

61. L. G. ALONSO GETINO, Vida, 337.

62. I. G. ALONSO GETINO, Vida, 368. 
radical", fuera de la banal consideración de que es propio de nuestra naturaleza, inexperta e inconstante, hastiarse, una vez conseguido, de aquello mismo de que se hacía cuestión de vida el obtenerlo ${ }^{69}$.

Pienso que el cambio en cuestión es real, y que no afecta sólo ni principalmente al carácter y las costumbres. Dudo que, en el sentido fuerte de la palabra, fray Luis se doblegara entrando por el camino de las virtudes convencionales. Por el contrario, entiendo que nunca fue más él mismo, que adquirió conciencia de su genio $\mathrm{y}$ vio claro en su camino. Esto le dio fuerzas para acelerar la redacción de sus escritos. Por cierto orientándolos con firmeza en la dirección por la que antes había ido caminando a tientas sin encontrar para la riqueza de sus pensamientos el molde justo. Ese molde tuvo que inventárselo y, como parto de un alma madura, el fruto fue también maduro. Pocas obras en nuestra literatura, y menos en la de pensamiento, producen a su lectura, en quien sea capaz de ella naturalmente, una sensación de firmeza de línea en el discurso y de plenitud de contenido, como los Nombres de Cristo. Bataillon vio muy claro este punto y dejó constancia de él, con palabras justas, al ocuparse de esa obra en su Erasmo y España ${ }^{64}$.

Relacionado con ese cambio ha de entenderse aquella otra actitud suya ante la historia cuyo sentido se resumió en la segunda de las proposiciones adelantadas al comienzo. Su comparación con el sentido expresado en la primera representa el paso de una concepción de lo histórico en la memoria y su concepción en la esperanza. La ósmosis entre memoria y esperanza hemos dicho que no estuvo ausente antes; tampoco lo estará después. Mas ahora predominarà una visión en la que se dejan de lado consolatorias añoranzas de un ideal para ser sustituidas por la experiencia viva de un concreto designio salvador. Su mirada orientada anteriormente por lo arqueológico va a orientarse por lo escatológico. Muy en consonancia con los gustos actuales se adelantó a proponer un enfoque teológico en base a una doctrina de novissimis. El mesianismo congenial de su alma recibe asi expresión en forma cristiana. $\mathrm{Su}$ cristología será el lado fuerte de su originalidad. En la figura de Cristo y en su obra redentora encontrará el centro de afirmación de la historia y el eje sobre el que ordenar su sentido.

Para documentar este punto podría aducirse abundante mate-

63. I. G. ALONSO GETINO, Vida, 338.

64. M. BATAILLON, Erasmo y España, II, 386; $390 ; 392$. 
rial. En gracia a la brevedad quiero ceñirme a los lugares que creo más significativos, que se encuentran en los Nombres y en el comentario triple latino al Cantar.

Pero me interesa volver por un momento la consideración a su obra poética. De toda su producción escrita únicamente en ella se encuentran textos que pertenecen unos al periodo anterior a la cárcel y otros posteriores; también los hay que fueron compuestos en la prisión ${ }^{65}$. Existe la dificultad de que la edición de su obra poética fue póstuma (1631), hecha, como es sabido, por Quevedo. Sabemos además que retocó una y otra vez los originales ${ }^{\circ}$. De todos modos un análisis estructural detenido de la diversas composiciones revelaría interesantes datos sobre las fases de su evolución, poniendo al descubierto los distintos esquemas mentales utilizados para alojar su inspiración. También podría obtenerse mediante este recurso un criterio suplementario en orden a datar las fechas de redacción de sus poemas. El criterio operaría con la hipótesis que hemos indicado; a saber, el predominio de uno $u$ otro de los modelos en su modo de concebir la historia.

Es cosa admitida, por ejemplo, que su oda de la "Vida retirada" es de las primeras de las por él escritas. Invitamos al lector que ponga a prueba la hipótesis. Verá cómo en dicha oda, con intercalados que hasta pueden considerarse sobrantes, tal vez ocasionalmente añadidos en alguna corrección ${ }^{67}$, el ritmo de las estrofas reproduce la imagen que del mundo pudo tener Platón y la que tantas veces ocurre en la literatura estoica, como puede ser la que contiene la Carta 90 de Séneca ${ }^{68}$ : la edad de Cronos que envejece diría Platón ${ }^{69}$ o la edad dorada que se deteriora para Séneca. Junto con ello la imagen del sabio, que cae en la cuenta de los males presentes, que los pinta incluso con negros colores, y recapacita para encontrar y mostrar el camino de su remedio. En la primera estrofa de fray Luis se adelanta en forma de tesis la sustancia de cuanto se desarrolla en las restantes.

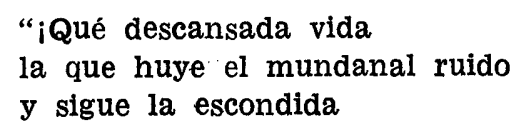

65. Sobre la datación de la obra poética de fray Luis se han interesado investigadores y críticos como Conster, Llovera, Vega. Una presentación general del asunto puede verse en A. F. G. BELL, Luis de León, 251-253.

66. A. F. G. BELL, Luis de León, 253.

67. A. F. G. BELL, Luis de León, 266.

68. Cartas a Lucilio, 90.

69. El politico, 271 e. 
senda por donde han ido

los pocos sabios que en el mundo han sido! ${ }^{70}$.

No hay una sola palabra sobrante en la estrofa. Casi todas ellas están en la memoria de la gente, y hasta han pasado al lenguaje proverbial para decir con ellas cosas que afecta a la sustancia del vivir humano. Su exégesis nos distraería del propósito que al presente nos interesa, ya que tras su inmediata transparencia laten significaciones henchidas de resonancias cultas que denuncian un estilo de vida y una manera de representarse el mundo. Recordemos que ese poema relaciona a fray Luis, a través del neopagano Garcilaso, con el pagano Horacio ${ }^{71}$. Los motivos centrales de la estrofa transcrita pueden reducirse a tres: 1) la "descansada vida" como arquetipo ahistórico que se añora. 2) "El mundanal ruido", que posteriormente se describe y del que se propone la huida. 3) "La escondida senda" seguida por "los pocos sabios", que se recobran del estado de deterioro mundano recuperando los bienes de los origenes. Los sabios que han sido y la senda por donde han ido señalan la orientación de la vida feliz, plena y auténtica. Programa vuelto hacia el pasado, memorizando, sin ansias de renovación. El tiempo permanece detenido. Se acalla el ansia de futuro y queda sin función la esperanza. No hay en efecto en todo el poema ni un solo verbo en tiempo de futuro. Sobre el fondo del modelo ideal de vida que se orienta por el pasado se enumeran en presente los mundanales ruidos de los que no se cura, de los que huye, o los que rechaza el que sigue el ejemplo de los sabios. También en presente, pero con valor de vuelta a lo natural, a lo que desde el principio es sencillo e inocente, se describe el vivir consigo mismo, en el huerto, "del monte en la ladera", regado por la "fontana pura", libre de cuidados. La expresividad subjetiva queda acallada en la representación de un ideal significado en la impersonal armonía de la naturaleza.

Disposición muy distinta es la que aparece en aquellas poesías que datan de los años que siguen al cautiverio, como son las odas, "Cuándo será que pueda" (a Felipe Ruiz), "Noche serena" (a Diego Olarte), "De la vida del cielo", "En la Ascensión". El motivo celeste sustituye al naturalista. La expresividad anima en todas ellas a la representación. El alma del poeta suspira por lo que espera.

El tiempo tiene dos caras. Hay el tiempo ruidoso del mundo, que

70. $P$, "Vida retirada", 1450.

71. A. F. G. BELL, Luis de León, $266 ; 276$. 
devora - "hambriento"-, desnuda, "con la mente conjurado", a cuantos le sirven, dejándolos sumidos en males y en olvido ("A un juez avaro"): "la esperanza buena" no es su compañía. Pero hay también el tiempo celeste,

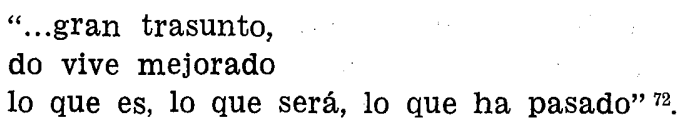

La haz de las cosas es signo o "nunto" de una entidad que las trasciende. No están ahi para volverse a ellas y aquietarse en su armonía, sino para hacer memoria del bien que se espera, donde la memoria se convierte en mediación de la esperanza. Lo que ahora busca fray Luis no es librarse de cuidados, aunque lo suponga, sino la libertad para acceder a la

"clarísima luz pura

que jamás añochece" 73.

La bucólica primavera de la "Vida retirada" queda fuera de contexto:

"Eterna primavera aquí florece" "4."

La imagen de la vida feliz, que encontraba su arquetipo en el pasado lo encuentra ahora en el futuro. En ese futuro se reencuentran los bienes de los orígenes, pero no en el estado de nacidos, si-

72. $P$, "Contra un juez avaro", 1476; "Noche serena", 1472.

73. $P$, "Noche serena", 1473.

74. $P$, "Noche serena", 1473. Predomina, en cambio, la llamada de los modelos antiguos en la oda "Las Serenas, a Querinto", en la que el clima del discurso se centra en Ulises, el "alto Griego", navegante de "Vuelta". hacia "sus tierras", roto el encanto de las sirenas, recobrado el tino, cuando "ya la madura edad te pide el fruto de gloria verdadera" (p. 1474). Comparar con "Al Licenciado Juan de Grial", composición que "debe ser grata especialmente a los intelectuales", según Dámaso Alonso (Vida y poesía en Fray Luis de León, Madrid 1955, 21), grata por su invitación al recogimiento y la entrega "a los estudios nobles". Parecen reffexiones de madurez, que, según la última estrofa, embargan al vate "en medio del camino", al verse acometido y derrocado por el torbellino de la suerte. El esquema de estas piezas corresponde al primero de los modelos indicados. Hay que advertir, de otra parte, que no es en la poesía donde más claramente se percibe el doble enfoque mental por el que venimos interesándonos. Los modelos clásicos pesan aquí más directamente en fray Luis. Campea en ellas un tono constante que tiñe de idealidad su visión y la consagra en una región como fuera del tiempo. Una y otra vez ocurre el doble tema del despego del ruidoso ajetreo diario y la añoranza de la serenidad, la armonía y la paz en lo eterno: cf. D. ALONSO, Poesía española. Ensayo de métodos y límites estilísticos (Madrid 1950) 196. 
no como término y plenitud de un renacer al que se le ofrecen en promesa. El vocabulario empleado por fray Luis sigue pegado a las imágenes y representaciones heredadas en las que hay reminiscencias, por ejemplo, platónicas; "el suelo, de noche rodeado", "esta cárcel, baja, oscura", "libre de esta prisión", "en luz resplandeciente convertido", "contemplar la verdad pura...". Mas el uso que hace de ese vocabulario y la función que cumple nos lleva a un discurso que exige clave interpretativa nueva. Hay que añadir, sin embargo, que en su poesía fray Luis no se desprende de los moldes clásicos, ni en la forma ni en el fondo. También Platón tenía orientada su alma hacia la "eterna primavera" y hacia el tiempo del cielo. El tiempo mundano es un lugar tramposo del que habria que desembarazarse. Si fray Luis en este punto introduce diferencias es porque, de una parte, en los sucesos de ese tiempo mundano ve "nuntos", es decir, anuncios del "bien divino" que se espera, y, de otra, porque ese "bien divino" no es un abstracto lugar de contemplación donde reinan las Ideas, sino el reino de un Dios vivo personal. La fertilidad de esta asunción cristiana en orden a su concepción de la historia se hará ver en otros de sus escritos donde toma la teología en serio, más que en la obra poética: "obrecillas" por él llamadas, que, en la mocedad, y casi en la niñez — nos dice-, entre las ocupaciones de sus estudios, se le van cayendo como de entre las manos ${ }^{75}$.

Decíamos que los tiempos verbales en "Vida retirada" tienen todos forma de pasado o de presente, y que, incluso en sus formas de presente, tienen la función, bien de negar el tiempo, bien de resolverlo en la armónica quietud de la naturaleza. Si el lector consulta una vez más la primera de las odas posteriores a la prisión antes consignadas se encontrará con que los verbos en que se apoya el movimiento estrófico, no todos, pero sí los que son eje de ese movimiento, son futuros. El poema empieza así:

“¿Cuándo será que pueda

libre de esta prisión volar al cielo?" "76.

No se trata, pues, de añorar una vida descansada en. lo que ha sido, sino abierta a lo que será. Como tampoco de verse libre de la prisión, sino de "volar". En las liras siguientes, con ritmo repetitivo, aparece el futuro "veré", hasta en ocho estrofas distintas. Se-

75. $P$, Dedicatoria" 1447.

76. $P$, “A Felipe Ruiz", 1464. 
ñalamos como significativo el que sea un término relacionado con la "teoria" -ver - el que se repite. En ello demuestra fray Luis mantenerse dentro de la orientación contemplativa en que venía resolviéndose la metafísica desde los griegos. Frente a esa "metafísica del ver", la inspirada en la Biblia ha sido calificada "metafísica del oír" ". A cada una de ellas corresponde un concepto distinto de verdad y diverso modo de regirse por ella la vida. La verdad en el primer caso es idea que pone de manifiesto y define el ser de las cosas. En el segundo es fidelidad en respuesta a una apelación. La sabiduría es allí conciencia que sabe de esencias, causas y principios mientras que aquí es conciencia temerosa de Dios, atenta a los designios de su voluntad y a la escucha de su voz. El "alma hebrea" atribuida, no sin fundamento, a fray Luis obliga a entenderle dispuesto a secundar esa segunda forma de sabiduria ${ }^{78}$. Ello tiene relación directa con la sensibilidad para la historia.

77. Cf. U. DUCHROW, Sprachvertändnis und biblisches Hören bei Augustin. Tubinga, 1965; C. TRESMONTANT, Estudios de metafísica biblica. Madrid, 1961 .

78. A. F. G. BELL, Luis de León, 251. Esta disposición es la que obliga a atribuir a fray Luis un ánimo orientado en su compresión del mundo sobre un discurso profético más que poético. En este sentido, y en cuanto a actitud mental básica, su espíritu se ve atraído por la philosophia Christi, que saca a luz misterios, que son llamadas de vida, y que se desentiende de las construcciones metafísicas expresadas en "razones necesarias" afirmadas en la eternidad. No es cuestión de ponderar aquí la transformación que implica este cambio, en el que el pensar se desplaza de lo noético a lo hermenéutico, cuyo organon es una "lógica de doble sentido", y connota discursos en los que "aparece una realidad y se oculta otra dentro de ella", en los que "en lo aparente se revela lo latente": (Opera, I, 1-3). Ese pensar frailusiano reviste caracteres de notable actualidad. El conocimiento que de él se tiene no hace justicia a su verdadera significación. Atendiendo a esta factura de su alma es como Kottman ha podido vincular su obra a la tradición mística judía, registrando influjos de la cábala hebrea en ella, que dicho autor considera decisivos (K. A. KOTTMAN, Law and Apocalypse. The moral Tought of Luis de Leon. La Haya, 1972; cf. A. HABIB ARKIN, La influencia de la exégesis hebrea en los comentarios bíblicos de fray Luis de León. Madrid, 1966, donde no sólo reafirma "las varias influencias hebraicas en la producción literaria de fray Luis de León", sino que trata de despojarla documentalmente "establecida y probada" (p. 3). El propósito central de este libro será el demostrar que fray Luis de León se valió de la exégesis hebrea al elaborar sus propios comentarios y traducciones" (pp. 4; 185-187). El padre David Gutiérrez, buen conocedor de la materia, al registrar las "fuentes e ideas fundamentales" de la "espiritualidad" de fray Luis, conociendo el estudio de Kottman, no parece reservar para los influjos en que este último se extiende ningún lugar apreciable, aunque implícitamente se admitan presentes a través de su constante y central interés por la Escritura. Lo que, por la documentación que el propio $P$. Gutiérrez alega, puede darse por confirmado, es la presencia que en su obra tienen ciertos escolásticos, los Padres de la Iglesia, entre ellos san Agustín, y también los filósofos griegos, especialmente Platón, todo lo cual rebaja la fuerza de la tesis de Kottman. Los mismos temas y motivos que en ella se subrayan pueden llegarle al Maestro salmantino por cauces diversos, encontrando en su sensibilidad campo bien dispuesto para aceptarios, máxime cuando podía verse apo- 
La primera observación que cabe hacer en orden a determinar su concepto de la historia, según el modelo segundo de los apuntados, tiene que ver con la "metafísica del oír"; y deriva del valor y función por él atribuido a las palabras. Es, a este respecto, particularmente instructivo el desarrollo de la "Introducción" a los Nombres de Cristo. Palabras son los nombres que están en la boca, pero, sobre todo, los que "están en el alma". No niega que éstos sean semejantes de las cosas, antes dice que son su "semejanza natural"; y que los nombres verdaderos son aquellos que les vienen a las cosas "como nacidos" de ellas, diciendo lo que tienen de más propio suyo ${ }^{79}$. Pero las cosas son respuestas a la palabra de Dios en la que reside la fuerza de dar, es el ser. De modo que la creación ha de entenderse en un contexto de vocación y respuesta: Dios dijo y lo dicho respondió como hecho. El mundo no descansa en la naturaleza de sí mismo, sino en la acción divina. Se dejó oír la voz divina, y en ella y por ella empezó a existir la realidad creada. Pero Dios no habló y se fue. La virtud de la voz divina sostiene y alienta de continuo a lo creado. Es ella la que lo mantiene en su ser. De modo que los nombres de las cosas, que les vienen como nacidos, en realidad son respuestas a la vocación divina que las hizo nacer. Cuando fray Luis habla de la naturaleza habla de las cosas de Dios, que son como el habla divina, por ser a la escucha de su voz.

La voz de Dios que se dejó oír al crear todas las cosas y al sostenerlas en su ser creado, se hizo oír de modo especial al hombre sobre el que abrigaba particulares designios. Decaído por la culpa de su buen natural de origen le habla para recrearle. Esa voz dirigida al hombre no termina en hechos consumados, como tampoco ocurría con la voz creadora. Por la voz dirigida se acomoda a la condición de su ser, regido por una mente, por la que es semejante a Dios mismo, capaz de decisiones responsables, dentro de los designios divinos. En la vida del hombre concurre la naturaleza respondiendo a la voz creadora y la gracia respondiera a la voz redentora. El discurso redentor no se superpone de por fuera al creador, sino que le da plenitud. La acción creadora se cumple en el hombre como dignación deificadora.

yada por una difusa mentalidad de época, consonante con sus inclinaciones íntimas, con las de círculos de cristianos al unísono con ellas y con las de grupos de intelectuales cercanos a su trato y amistad. (Cf, D. GUTIERREZ, "Fray Luis de León autor místico": Religión y Cultura (1976) 33-40).

79. NC, "De los nombres en general", 395-396. 
Para lo que aqui interesa, y sin perjuicio de volver sobre este punto, ello significa dos cosas. Primera, la obvia comprensión del mundo y especialmente del hombre como historia. Segunda, la relación de esa historia con la fuerza de la palabra.

El alma de fray Luis fue extraordinariamente sensible a esas dos realidades. Sobre la primera insistiremos enseguida. Sobre la segunda baste consignar como rasgos de su forma mentis el despego que sintió hacia la filosofía escolar, que no despreció, pero sí denunció cuando en ella, y dentro de la metafísica griega del ver, puede recibir aportaciones de diversa procedencia. Pero la fuente quiso encerrarse el caudal de la sabiduría teológica. La teología última de ella está en la palabra revelada. Esto no era negado por ningún teólogo, al menos teóricamente, mas en la práctica era como si lo negasen por la importancia concedida a la especulación escolástica y por las reservas que parecían mostrar ante la eventualidad de encontrarse con los textos escriturarios en su verdad no adulterada. Ir a las fuentes para restituir la verdad de los textos era un asunto que en principio tampoco podía ser discutido. Pero se daba el caso que los textos admitidos y que muchos consideraban intocables por haber sido canonizados por la Iglesia, para un conocedor de las lenguas originales como era nuestro autor no sólo admitían sino que exigían correcciones. Esta fue la raíz de los más serios de los contratiempos con sus colegas, que dieron por resultado su encarcelamiento. Para un hombre convencido de que la verdad estaba en la palabra de Dios, y que ésta era la recogida por los agiógrafos, y no otra, no había alternativa; la que le proponían sus oponentes era inaceptable, al menos había que explicarse sobre ella.

En todo caso, fray Luis consagró su vida a desentrañar los sentidos de la Escritura y todo su pensamiento se organizó en torno a la palabra revelada. No tenía por qué escribir sistemas bien razonados. Lo que tenía que hacer es lo que hizo: traducciones escrupulosas, porque el que traslada, máxime en "Escrituras de tanto peso", "ha de ser fiel y cabal y, si fuere posible, contar las palabras para dar otras tantas, y no más ni menos, de la misma cualidad y condición y variedad de significaciones que las originales tienen, sin limitarlas a su propio sentido y parecer..." ${ }^{80}$. Aparte de esto lo que tenía que hacer era "explicar y declarar", es decir, hacer de comentarista e intérprete del sentido o sentidos de los textos. $Y$ esto es 10 que hace. La obra por la que fundamentalmente se le conoce es de

80. CC, "Prólogo", 29. 
traductor de la Escritura y de comentarista de algunos de sus libros o de una selección de sus textos. Nada más revelador, a este respecto, que el título de su obra sobre los Nombres de Cristo. Lo que había que decir sobre el misterio cristiano no habia que ir a buscarlo a la metafísica, lo decían los "Nombres" que la Escritura aplica a Cristo, que son los que Dios mismo nos reveló como los más propios suyos; y tomarlos de allí como de su fuente, del hebreo, lengua que, para fray Luis, dentro de los conocimiento de la época, siguiendo en este caso a san Agustín, era la lengua más antigua ${ }^{81}$.

Vossler atribuye a fray Luis "un instinto lingüístico tan sutil como seguro" 82. En otro lugar habla de que "era una naturaleza magníficamente dotada desde el punto de vista lingüístico y que las restantes cuestiones de la vida le parecían resolverse casi por sí mismas a través de la creación poética y de la traducción e interpretación de formas lingüisticas". Ahora bien, su independencia y agudeza en cuestiones filógicas" ${ }^{83}$ delata algo más que unas destrezas profesionales, por lo demás escasamente compartidas en aquel tiempo. Reflejan una inclinación profunda die su alma, en consonancia con la cual se daba una forma de ver el mundo, precisamente la que le disponía a experimentarle como historia.

\section{La renovación de las edades y la plenitud de los fines}

Quedamos en que fray Luis de León no es historiador. No esperemos, por tanto, de él información erudita sobre las gestas o fechorias de la humanidad, semblanzas de personas, anales de reinados, crónicas de épocas o epopeyas de pueblos: no esperemos historias.

No son esas historias positivas lo que le preocupa. Sin embargo, no se comprende el objeto de su preocupación sin tener por fondo la historia. La historia es entonces su tema. Pero no en cuanto ha sucedido esto $o$ lo otro en el tiempo, sino en cuanto en ese suceder se lee escrito el destino humano, o transparentándose en él se entiende. También en el caso de su primera relación con lo histórico a la que nos hemos referido. Pero esto se hace más patente en la forma segunda de esa relación de la que vamos a ocuparnos.

El destino humano o el sentido de la existencia es entendido por fray Luis en clave religiosa. De modo que la historia que le in-

81. C. VOSSLER, Fray Luis de León, 23; cf. nota 43.

82. C. VOSSLER, Fray Luis de León, 44.

83. C. VOSSLER, Fray Luis de León, 48. 
teresa es la que se resuelve en escenario de los gesta Dei. Su interés, por consiguiente, es teológico. El desarrollarlo pertenecería a los clásicos tratados De creatione o/y De Redemptione. Por resumirlo, su interés al caso será el de un teólogo de la historia. No le preocupan las cosas que han sucedido sino los significados que contienen y los designios que cumplen.

El resultadu a que llega es algo más que descubrir un orden providente de los acontecimientos. Este orden puede llamarse natural y de él hablaron largamente con sus luces los filósofos. El orden con que fray Luis se entiende no tiene que ver con filosofos sino con profetas. No sucede por explicación de causas, sino por revelación de misterios. Así que nos conduce a un conocimiento que consiste en interpretar signos en los que bajo la letra se muestra el espíritu. Lo que aparece remite a lo que se esconde, siendo lo que se esconde la clave de lo que aparece. No se dedica a darnos razones sino interpretaciones. El texto que ha de interpretar es revelado, es para entenderlo hay que ponerse solícitamente a su escucha y no decir comunicado personalmente por Dios al hombre, de forma que para entenderlo hay que ponerse solícitamente a la escucha y no perder palabra, entendiendo cada una de éstas como mensaje que nos dice secretos que es inútil curiosear en otra parte. Esas curiosidades podrán servir como instrumento comprensivo auxiliar, nada más. Así pues, fray Luis se pone a escuchar los dichos de Dios revelándose en la Escritura, en comunión a la misma escucha con la Iglesia. En la clave de esos dichos interpretará los hechos. La revelación tiene diversos sentidos, pero el más profundo profetiza misterios secretos ${ }^{84}$. Al hilo de esa profecía se entiende la historia, que será por consiguiente "historia profética".

Empecemos por el modo de presentarla en los Nombres de Cristo. Podemos ordenar su pensamiento al caso en dos apartados que se complementan. En el primero nos hace ver la historia en su hacerse continuo cumpliendo los planes de Dios. En el segundo, tomándola en conjunto, periodiza sus edades. En uno y otro caso la sabiduria en acción será la profética abierta al tiempo y señaladora de cumplimientos de futuro. Por tanto el arquetipo de la vicisitud humana no se encuentra en el pasado, un pasado bloqueador de lo nuevo, al que siempre hay que volver como a la edad plena después decaída. Por el contrario, en la nueva visión los tiempos se renuevan y la vicisitud humana es ida hacia adelante en un proceso de consumación. Sin duda el cristiano fray Luis habla de una "plenitud de los tiempos", cumplida en Jesús de Nazareth, que; en

84. CC, "Prólogo", 27. 
la historia positiva es un hecho del pasado; pero el Cristo vivo no se agota en ese hecho: es el resumen de la historia profética, centro y eje de todo su discurso.

En uno de los primeros párrafos del Nombre "Faces de Dios" se refiere a la escena del Exodo $(3,14)$ en que Elohim confía a Moisés su misión para con el pueblo judio y le pide su nombre, ese nombre, según la traducción de fray Luis es ésta: "El que seré, seré, seré, me envía a vosotros". Y comenta: "repitiendo estas palabras de tiempo futuro tres veces", es como decirle:

"Yo soy el que prometí a vuestros padres venir ahora para libraros de Egipto, y nacer después entre vosotros para redimiros del pecado, y tornar últimamente en la misma forma de hombre para destruir la muerte y perfeccionaros del todo. Soy el que seré vuestra guía en el desierto, y el que seré vuestra salud hecho hombre, y el que seré vuestra entera gloria hecho juez" ${ }^{85}$.

Dice de estas palabras que son como la consigna o contraseña, de uso militar, "que está en secreto entre solos el capitán y los soldados que hacen cuerpo de guardia", a "lo que en la guerra decimos dar nombre" ${ }^{86}$. Como ese "dar nombre" es el que Elohim se da a sí mismo diciendo quién es, Dios revela su ser nombrándose. Los "nombres" dirán a fray Luis todo el secreto de los misterios divinos. $\mathrm{Y}$ porque "Dios por medio de Cristo quiere ser conocido; y el que sin este medio le conoce, no le conoce" ${ }^{87}$; los "Nombres de Cristo" serán todo el secreto de los misterios de Dios.

El más condensado resumen de la historia profética se encuentra en el nombre "Pimpollo". En él "se toca en cierta manera la cualidad y orden del nacimiento de Cristo y de su nueva maravillosa regeneración". $Y$ se declara de esta manera: Dios crea el mundo con cuantas cosas contiene "para comunicarse El a si y para repartir en sus criaturas sus bienes" ${ }^{88}$.

En la traza de la creación aparece pues la obra de Dios como difusión del bien divino, como comunicación de Dios mismo a lo creado. El universo que se nos muestra aparentemente estacionado en un contexto de ser, considerado por dentro nos habla el discurso de la bondad. Se dice discurso porque la ontología de la bondad que

85. NC, "Faces de Dios", 422-423.

86. NC, "Faces de Dios", 424.

87. NC, "Faces de Dios", 433.

88. NC, "Pimpollo", 410. 
en él está en juego es dinámica: todo se junta con Dios como fruto de su bondad comunicativa. Las maneras de esa comunicación son tres, a saber, "por naturaleza o por gracia o por unión personal". Y se nos explica: "A la naturaleza pertenecen los bienes con que se nace; a la gracia pertenecen aquellos que después de nacidos nos añade Dios. El bien de la unión personal es haber juntado Dios en Jesucristo su persona con nuestra naturaleza" ${ }^{89}$. La comunión en el "bien divino" se manifiesta con intensidad muy diversa en cada uno de esos grados. En el aspecto extensivo todas las criaturas se avecinan a Dios en los bienes de la naturaleza, y sólo las dotadas de entendimiento en los bienes de gracia. En cuanto al bien de la unión personal, aunque hecha en la naturaleza humana, "en juntarse Dios con ella, es visto juntarse con todas las criaturas, por causa de ser el hombre como un medio entre lo espiritual y lo corporal, que contiene y abraza en sí lo uno y lo otro. $Y$ por ser, como dijeron antiguamente, un menor mundo o un mundo abreviado" ${ }^{90}$.

Si el fin de crear Dios todas las cosas fue solamente el de comunicarse con ellas, de tan gran Artífice era de esperar la más perfecta forma de comunicación, que se cumple en la unión personal. De donde se sigue que a esa unión está enderezada la obra creadora: "El fin para que fue fabricada toda la variedad y belleza del mundo fue por sacar a luz este compuesto de Dios y Hombre, o, por mejor decir, este juntamente Dios y Hombre, que es Jesucristo". De modo que Dios hizo el mundo "para fin de hacer Hombre a su Hijo". Cristo es el fin de lo creado: "parto común y general de todas las cosas", en el que "se recapitula todo lo no criado y criado, lo humano y lo divino, lo natural y lo gracioso" (Col 1, 20). Le conviene pues a Cristo ser llamado "fruto del mundo" 1 . "Todo aquello que es verdadero fruto en los hombres, digo fruto que merezca parecer ante Dios y ponerse en el cielo, no sólo nace en ellos por virtud de este fruto, que es Jesucristo, sino en cierta manera también es el mismo Jesús". Fray Luis acude a san Pablo y a san Agustín invo-

89. NC, "Pimpollo", 410-411; Opera, IV, 25-26; 30-58; VII, 244-273; DI, X, 386-388; cf. S. FOLGADO FLOREZ, Cristocentrismo teológico en Fr. Luis de León (El Escorial 1968) 71-73; S. MUÑOZ IGLESIAS, Fray Luis de León, teólogo (Madrid 1950) 101-103.

90. NC, "Pimpollo", 412. La consideración del hombre como "minor mundus", "mundus abreviatus", "imago totius mundi", "vinculum naturae", "microcosmos...", siguiendo una tradición que viene de los griegos y que fue recogida por numerosas figuras del Renacimiento, aparece con frecuencia en la obra de fray Luis: (Opera, II, 248; IV, 26; VII, 202; 372; cf. J. GARCIA JAEN, La antropología en fray Luis de León [extracto de tesis doctoral], Madrid 1974, 3-7).

91. NC, "Pimpollo", 413; "Amado", 744; "Jesús", 789; S. FOLGADO FLOREZ, Cristocentrismo teológico, 76-77. 
cando la doctrina del cuerpo místico, en el que "los miembros y la cabeza son un solo Cristo" ${ }^{92}$.

He ahi un lenguaje que nos habla de obras, fines y frutos; es decir, un lenguaje de acción, que nos emplaza ante un soberano plan divino cuya ejecución es la clave para comprender el universo. Universo no cerrado sobre sí mismo y concretado en esencias para contempladas, sino cumpliéndose en abierto proceso realizador. El orden cósmico centrado en sí se convierte en discurso de sentido, donde lo escatológico es clave de lo ontológico. Ello significa asumir la historia como entraña de una realidad que es manifestación del obrar divino.

Pero esa concepción de lo creado que tiene por eje y por meta a Cristo, recapitulando en sí todas las cosas, si por una parte da la imagen de los planes divinos sobre el mundo, por otra, dentro de su grandiosidad luminosa, encubre aspectos oscuros y perturbadoras complejidades. El pecado entró en el mundo, y con él "quedó extrañamente dificultoso y revuelto este negocio del hombre". En los decretos divinos el hombre estaba destinado a ser señor de todo lo creado y gozar de plenitud de vida. Pero, como ser libre, su destino quedó confiado a su juicio. No usó de ese juicio rectamente, y, con el pecado, quedó efectivamente revuelto el negocio del hombre. Dios había sentenciado esa eventualidad con la privación de la vida. Aparecen esos dos decretos como en pugna, el de la plenitud de vida en la inocencia y el de la privación de vida en el pecado. Alternativa que no parece admitir término mediador. Puesto que el hombre pecó, uno de los extremos, el lamentable, era el ordenado a cumplirse. Pero Dios halló el medio de salvar la dificultad, y fue el de restaurar lo perdido, no acabando con el hombre, poniendo en su lugar otro linaje de seres, sino haciéndole nacer de nuevo ${ }^{93}$. El modo y manera de esta dignación divina encierra el secreto de la Redención. Desarrolla fray Luis este central capítulo de la fe cristiana, entre otros lugares, ya que el tema le preocupó hondamente, en el Nombre "Padre del siglo futuro": fórmula cargada de significación en cada una de sus palabras en relación con la historia; en ella, en efecto, se nos habla de generación al mencionar al "padre", y es generación de edades y mirando al "futuro" ${ }^{4}$.

Fray Luis, por otra parte, no supedita la Encarnación al pecado

92. NC, "Pimpollo", 410-416.

93. NC, "Padre del siglo futuro", 485; "Dedicatoria" al lib. II, 522-523 ; "Brazo de Dios", 546.

94. NC, "Padre del siglo futuro", 483-485. 
de Adán. El decreto de Encarnación del Verbo fue absoluto, independiente de la Redención; de modo que, contra la tesis tomista, abraza la de Escoto: aun sin el pecado de Adán se habría encarnado el Verbo ${ }^{95}$.

Esa tesis abre horizontes especialmente adecuados para dar cabida en ella a la acción de Dios en el mundo como historia.

De naturaleza imperfecta -el hombre- por su primer nacimiento, es "como si dijésemos comenzada a hacer". Su voluntad y libertad le facultan para "acabarse y figurarse" a su elección. De suyo el hombre no tiene forma, "es capaz para todas, y maravillosamente fácil y como de cera para cada una de ellas". De esa capacidad deriva el ser bueno o ser malo, de modo que en él está que "sea lo que hace". En esto puso Dios su mano y, sobre la sustancia natural añadió los dones de su gracia, y así "sacólo como si dijésemos de un golpe y de una vez acabado, del todo y divinamente acabado". Según su natural podía acabarse dañadamente. La figura que recibe con la gracia la hace otro Dios, "imagen suya sobrenatural y muy cercana a su semejanza". Aunque todo esto lo perdió por el pecado, siendo fruto suyo el "hombre viejo", que es lo que le quedó como hechura de Adán, sin lo que tuvo Adán de Dios, mas "lo que él hizo en sí por su culpa y por virtud del demonio" ${ }^{96}$. Aquí enumera fray Luis los estragos de esa hechura.

Los designios de Dios se revelan en la traza de proveer al hombre de un renacimiento, del que saldrá el "hombre nuevo", con espíritu y fuerza contrarias al viejo. Esto hizo Dios renovando su imagen en el alma de los hombres y adoptándolos por hijos suyos.

Juliano, que interviene, en este punto en el diálogo, reconoce que la exposición que sigue Marcelo no es nueva. Es, por el contrario, la suma de la doctrina esparcida por la Escritura y las obras de los Doctores que de ella se ocuparon. Pero queda sorprendido ante la coherencia dramática del conjunto. "Sois el primero - dicede los que he visto y oído yo que, juntando cada una cosa con su igual cuya es, y como pareándolas entre sí y poniéndolas en sus lugares, y trabándolas todas y dándoles orden, habéis hecho como un

95. Expone esa doctrina repetidas veces, especialmente en el Nombre "Pimpollo". Desarrolló en dos ocasiones el tratado De incarnatione, donde también se adhiere a ella; (Opera, IV, 30-58; VII, 244-273). La acción de Cristo dando vida al Cuerpo místico y conduciendo a la Iglesia hasta el triunfo final la ve profetizada en el Salmo 150, siguiendo a san Agustín; una vigorosa traducción de ese Salmo da cima a la exposición del Nombre "Padre del siglo futuro", 515-517; ¿. S. FOLGADO FLOREZ, Cristocentrismo teológico, 74 ; 92-99; cf. nota 89.

96. NC, "Padre del siglo futuro", 487-489. 
cuerpo y como un tejido de todas ellas". De modo que fray Luis cret ofrecer en: su disposición de conjunto una doctrina, sin duda sabida, pero que se abre a un nuevo modo de conocimiento ${ }^{97}$.

La sustancia de esa doctrina se resume diciendo que Dios "hizo un otro hombre, que es Cristo hombre, para que nos engendrase segunda vez, así como el primer hombre nos engendró la primera". Esta doctrina es breve de proponer, pero larga de explicar. $\mathrm{Ha}$ de entenderse en el sentido de que "Cristo nos reengendró y calificó primero en sí mismo, como en virtud y según la manera como en El estábamos juntos, y después nos engendra y renueva a cada uno por sí y según el efecto real" ${ }^{98}$. Lo primero haciéndonos unos en Cristo, recapitulándose en $\mathrm{El}$ todas las cosas ${ }^{99}$. Lo segundo transformando por dentro las almas, sin juzgar que, "con la que fue hecho en nosotros en la persona de Cristo, con eso, sin más hacer ni entender en las nuestras, somos ya en ellas justos y salvos, como dicen los que desatinan ahora" 100.

Apunta aquí fray Luis a la enseñanza protestante. Como todo lo que nace, el hombre renacido crece. Su crecimiento se cumple "por la gracia de Dios y por la industria y buenos méritos de nuestras obras que nacen de ella" ${ }^{101}$. El vocabulario que repetidamente utiliza en este caso fray Luis es tomado de la biologia, entendiendo, por analogia con la vida natural, la sobrenatural. Nos habla de nacer, renacer, vivir, madurar; de semillas, espigas, frutos... Todo lo cual nos sitúa de nuevo en un contexto dinámico.

En la última parte de la exposición sale, conforme nos dice, "a campo más libre". Declarando el significado de "siglo futuro" lo en-

97. NC, "Padre del siglo futuro", 493-494; 496.

98. NC, "Padre del siglo futuro", 500.

99. NC, "Padre del siglo futuro", 498.

100. NC, "Padre del siglo futuro", 494; 506. Le preocupó hondamente la conmoción de la Iglesia producida por el "error luterano", que entiende tiene su raíz en la mala inteligencia de la doctrina que desarrollan los pasajes aducidos en el texto, según nuestro autor entiende. Llega a concebir una obra especial dedicada a esclarecer los puntos controvertidos, aunque nunca la llega a publicar. Dice: "Y si tuviese yo lo que para esto es necesario de ingenio y de letras, y si me concediese el Señor el ocio y el favor que yo le suplico, por ventura emprendería servir en este argumento a la Iglesia, declarando este misterio y aplicándolo a lo que ahora entre nosotros y los herejes se alterca, y con el rayo de esta luz sacando de cuestión la verdad; que a mi juicio sería obra muy provechosa; y así como puedo, no me despido de poner en ella mi estudio a su tiempo" (p. 495; cf. Opera II, 261; 461).

101. NC, "Padre del siglo futuro", 494; "Jesús", 778-780. Bataillon le atribuye un erasmismo de actitud, que le llevaba a insistir en el "cristianismo esencial", poco aficionado a la "beatería", sin menoscabo, no obstante, de la "santidad exterior" (M. BATAILLON, Erasmo y España, II, 388; 389 ; 390). 
tiende refericio a la nueva generación del hombre, duradera por "largos y no finibles tiempos". Distingue entre el "siglo primero", al que pertenecen los hombres nacidos de Adán para la muerte, y el "siglo segundo" que, desde Abel, "en quien comenzó extendiéndose con el tiempo, y cuando el tiempo tuviere su fin, reforzándose él más, perseverará para siempre" ${ }^{102}$. Ese siglo segundo es el de la Iglesia, con su cielo y su tierra propios, que en su curso conoce "tiempos duros y ásperos", pero que camina a su perfeccionamiento, hasta verla sacada "toda junta y pura y luciente y verdaderamente nueva del todo... Cuando viniere este tiempo... ellos vivirán en Ti, y Tú vivirás en ellos dándoles riquísima y dulcísima vida... Serás Tú en ellos todas las cosas, reinarás para siempre" ${ }^{103}$.

En los nombres que siguen, "Brazo de Dios" y "Rey de Dios", se nos describe la traza de ese gobierno y su diferencia del que establecen los reinos del "siglo primero", que están a la muerte. La pintura que fray Luis hace de los Principes del mundo y de sus historias de dominio no es precisamente halagüeña ${ }^{104}$. El mismo instrumento de la ley que, de suyo, está ordenado a hacer justicia y establecer la paz se adultera en manos de los gobernantes, que amparan en ellas sus tiranías y antes que conducir al bien de los súbditos, sirve para tenerlos sojuzgados. Esas leyes que consisten en poner mandamientos, carecen de toda fuerza vivificadora interior ${ }^{105}$.

Para descubrir el buen gobierno del "siglo segundo" siempre fue flaca defensa asirse a la letra, cuando la razón evidente descubre el verdadero sentido" ${ }^{106}$. Eise sentido va haciéndose con suavidad, como yendo el mundo a su plenitud desde la espontaneidad de sí mismo, según leyes ocultas que saben sacar los más portentosos resultados de las causas aparentemente más despreciables, cual sobre todo se ve en el nacimiento y crecimiento de la Iglesia ${ }^{107}$.

Pasamos ya al segundo apartado, aquel en que, como "saliendo de entre zarzas y espinas a campo libre", los planes divinos son presentados en mirada de conjunto. El fructificar de Cristo en la Iglesia se ve discurrir por edades que marcan los distintos pasos de la "historia de la salvación".

Le vimos distinguir en la historia humana dos "siglos", que

102. NC, "Padre del siglo futuro", 512.

103. NC, "Padre del siglo futuro", 515.

104. NC, "Rey de Dios", 568, 581.

105. $N C$, "Brazo de Dios", 544-545; "Príncipe de la paz", 613-614; cf. S. AL-

VAREZ TURIENZO, art. cit. en nota 36.

106. NC, "Brazo de Dios", 534

107. NC, "Brazo de Dios", 547; 550; 554. 
aunque mezclados en el tiempo, se diferencian por el origen que tienen y la inspiración que los anima. El "primer siglo, que es el vivir de los que nacemos de Adán"; y el "siglo segundo", que es el de los renacidos en Cristo. El uno acaba en la muerte, y el otro en la consumación de la vida. Puede percibirse ahi, bajo nuevo ropaje, el tema agustiniano de las dos "ciudades" 108.

Refiriéndose a las palabras del Salmo 79: "Conviértenos, Dios de nuestra salud", observa fray Luis que se repiten tres veces, "en el principio y en el medio y en el fin del Salmo". Y entiende que de esa manera el Profeta pide a Dios en "tres lugares que convierta su pueblo a sí y le descubra sus Faces, que es a Cristo". Y añade cómo, en efecto, "son tres veces las que señaladamente el Verbo divino se mostró y mostrará al mundo". Las que se corresponden con otras tantas de comunicarle salud, marcadas por distintas dignaciones. "Porque lo primero se les mostró en el monte [a los judíos] adonde les dio ley y les notificó su amor y voluntad...; y comenzó a humanarse con ellos entonces, como quien tenía determinado de hacerse hombre de ellos y entre ellos después, como lo hizo. $Y$ éste fue el aparecimiento segundo, cuando nació rodeado de nuestra carne y conversó con nosotros, y viviendo y muriendo negoció nuestro bien. El tercero será cuando, en el fin de los siglos, tornará a venir otra vez para entera salud de su Iglesia" ${ }^{108}$. Esas tres venidas del Verbo las encuentra significadas en el texto del Exodo anteriormente aducido, cuando se presenta Dios a Moisés diciendo: "El que seré, seré, seré". Lo que para fray Luis significa todo el futuro del pueblo elegido, siendo el Verbo su "guía en el desierto", su "salud hecho hombre", su "entera gloria hecho juez" ${ }^{110}$.

Este esquema triádico lo encuentra realizado en la vida de cada persona, tanto la natural como la sobrenatural, siendo aquella como la imagen visible de lo que invisiblemente ocurre en ésta última.

\footnotetext{
"Y de la manera que nuestra alma en el cuerpo, desde luego que nace en él, nace toda, mas no hace luego que en él nace prueba de si totalmente, ni ejercita luego toda su eficacia y su vida, sino después y sucesivamente, así como se van enjugando con el calor los órganos con que obra, y tomando firmeza hábil para servir al obrar, así es lo que
}

108. NC, "Padre del siglo futuro", 512; cf. SAN AGUSTIN, De civitate Dei, $\mathrm{XII}, 27,2$; XIV, 1; XIV, 28; XV, 1, 1; De vera Religione, 27, 50.

109. NC, "Faces de Dios", 421-422.

110. NC, "Faces de Dios", 422-423. 
decimos de Cristo, que, aunque pone en nosotros todo su espíritu cuando nace, no ejercita luego en nosotros toda su vida, sino conforme a como, movidos de El, le seguimos y nos apuramos de nosotros mismos, así El va en su vivir continuamente subiendo. $Y$ como cuando comienza a vivir en nuestra alma, se dice que nace en ella, así se dice que crece cuando vive más; y cuando llega a vivir allí, al estilo que vive en si, entonces es lo perfecto. De arte que, según aquesto, tiene tres grados este nacimiento y crecimiento de Cristo en nosotros. El primero, de niño en que comprendemos la niñez y la mocedad, lo principiante y lo aprovechante que decir solemos. El segundo, de más perfecto. El último, de perfecto del todo. En el primero nace y vive en la más alta parte del alma. En el segundo en aquélla y en la que llamamos parte inferior. En el tercero, en esto y en todo el cuerpo del todo".

Al primero podemos llamar estado de ley, por las razones que diremos luego. El segundo es estado de gracia. $\mathrm{Y}$ el tercero y último estado de gloria ${ }^{111}$.

Explicando a continuación cada uno de estos estados, que, aplicados al alma, suponen entenderla según aquella filosofía que distingue en ella

"dos partes: una divina, que de su hechura y metal mira al cielo y apetece cuanto de suyo es... Otra de menos quilates, que mira a la tierra y que se comunica con el cuerpo, con quien tiene deudo y amistad, sujeta a las pasiones y mudanzas de él, que la turban y alteran en diversas olas de afectos... Estas dos partes son como hermanas nacidas de un vientre en una naturaleza misma, y son de ordinario entre si contrarias, y riñen y se hacen guerra. $Y$ siendo la ley que esta segunda se gobierne siempre por la primera, a las veces, como rebelde y furiosa, toma las riendas ella del gobierno $\mathrm{y}$ hace fuerza a la mejor..." 112 .

Sobre ese esquema ordena el nacer de Cristo en el alma, ganándola por grados, hasta extender su vida hasta la parte más baja de ella, lo cual es significado en el estado de gracia, hasta acabar su crecimiento en los suyos comunicando su espíritu y vida al cuerpo, "no solamente quitando de él lo vicioso, sino también desterrando

111. NC, "Hijo de Dios", 720-721.

112. NC, "Hijo de Dios", 721. 
de él lo quebradizo y lo flaco, y vistiéndolo enteramente de sí", grado tercero o de gloria de los indicados. Compara de paso el estado de ley con el de la edad del pueblo judío representada en Moisés ${ }^{113}$. Con estas edades del alma se corresponderán las de la historia.

Con las dos partes del alma relaciona también en este lugar "dos linajes de gentes enemigas entre sí, las que siguen en el vivir el querer del sentido, y las que miden lo que hacen por razón y justicia" 114. Frutos suyos son el doble gobierno que se hecha de ver en el mundo: el de los reinos que miran a la tierra y en los que domina el egoísmo, la envidia, la ambición; y el de Cristo, que mira al cielo sustentado en suave orden de amor encaminado a la paz.

La comparación temática entre los grados de crecimiento de la vida divina en el alma y la comunicación de Cristo a la Iglesia la hace comentando el Cantar de los cantares, que fue aquel, de entre los textos bíblicos, que más adentro le llegó, al que dedicó perseverante desvelo, todo lo cual hubo de acarrearle amargos sinsabores, fuera por la "envidia y mentira" de los demás, fuera por imprudencia propia. Ello es que, nos dice, "en estos Cantares, como en persona de Salomón y de su esposa, la hija del rey de Egipto, debajo de amorosos requiebros explica el Espíritu Santo la Encarnación de Cristo y el entrañable amor que siempre tuvo a su Iglesia, con otros misterios de gran secreto y de gran peso" ${ }^{115}$. Volvemos sobre el peso y secreto de esos misterios enseguida, para ver el significado teológico-histórico que se encubre en el cantar. Un adelanto de todo ello se encuentra en los Nombres de Cristo, precisamente en el capítulo "Esposo".

"Cristo se desposó con la Iglesia luego en naciendo ella o, por mejor decir, que la crió e hizo nacer para Esposa suya". $Y$ desde el principio "la ha ido criando y acariciando conforme a sus edades, y diferentemente según sus diferencias de tiempos... Porque toda la edad de la Iglesia, desde su primer nacimiento hasta el dia de la celebridad de sus bodas, que es todo el tiempo que hay desde el principio del mundo hasta su fin, se divide en tres estados de la Iglesia y tres tiempos: el primero que llamamos de $n a-$ turaleza, y el segundo de ley, y el tercero y postrero de gracia. El primero fue como la niñez de esta Esposa; en el

113. NC, "Hijo de Dios", 721-723.

114. NC, "Hijo de Dios", 727.

115. CC, "Prólogo", 27. 
segundo vino a algún mayor ser; en este tercero que ahora corre, se va acercando mucho a la edad de casar". "116.

En el primero de esos tiempos tenía "la Iglesia presente y como delante de los ojos dos cosas, la una su culpa y pérdida, y la otra la promesa dichosa de su remedio". En él no se le descubre el Esposo del todo: "la luz y el conocimiento que en aquella edad dio guía a la Iglesia fue muy pequeño y muy flaco conocimiento en comparación del de ahora" ${ }^{117}$. Se le pegaban errores y daños, le oprimía la servidumbre. Dura esa edad hasta la salida de Egipto. Se ve entonces libre de compañias malas, pero peregrina en el desierto entre dificultades y trabajos, y asi transcurre la segunda edad ${ }^{118}$. El paradero de esa peregrinación era "el llegar a la tierra que les estaba guardada [a los israelitas] y el alcanzar la posesión pacífica de ella. Con lo cual comienza la tercera edad de gracia" ${ }^{119}$, en el principio de la cual Cristo "nació cubierto de nuestra carne y vino así a descubrirse visiblemente a su Esposa, vestido de su librea de ella y sujeto, como ella lo es, a los trabajos y a las malas noches que en la oscuridad de esta vida se pasan". "El conocimiento pasado en comparación de la luz presente, y lo que supo de su Esposo la Iglesia en la naturaleza y en la ley, puesto con lo que ahora sabe y conoce, fue como una niebla cerrada y como una sombra oscurísima". Ha crecido "en todo género de espiritual hermosura; y no está como estaba antes, encogida en un pueblo solo, sino extendida por todas las naciones del mundo". Sólo le resta pedir que el Esposo venga a las bodas, y se le descubra el día de luz al que no sucede noche. A ese día corresponderá la edad de la gloria ${ }^{120}$.

Pues bien, todo el misterio que se descubre en los tiempos de la Iglesia y que pone de manifiesto la obra del Espíritu en la historia,

116. NC, "Esposo", 656-657. La descripción de las fases del crecimiento del alma, así como la periodización de la historia por edades cuenta con una larga tradición anterior a fray Luis; por ej., en san Agustín. Para lo primero, De vera Religione, 26, 48-49; De quantitate animae, 33, 70. Donde habla de "seis edades' de la vida del hombre tanto del hombre viejo como del nuevo, describiendo en este último otros tantos grados de crecimiento espiritual, hasta la séptima edad que será la de la "quies aeterna", que ya no admite edades. De las mismas seis edades habla con respecto al género humano, que se reducen a tres, y que se corresponden con las indicadas de fray Luis: "unum tempus computamus ante Legem; alterum sub Lege; tertium sub gratia" (De Trinitate, IV, 4, 7; De civitate Dei, XXII, 30-5).

117. NC, "Esposo", 659 .

118. NC, "Esposo", 660-661.

119. NC, "Esposo", 663.

120. NC, "Esposo", 663-665. 
lo encuentra fray Luis como en cifra y oculto tras la letra, en los versos del Cantar de los cantares. En el lugar indicado de los Nombres da su exacta clave interpretativa. El libro de los Cantares ofrece "el dibujo vivo" del amor entre Cristo y la Iglesia, el trato que ella de El ha recibido y el que ha de recibir, "hasta que llegue el dichoso día del matrimonio, que será el día cuando se cerraren los siglos" ${ }^{22 .}$. Punto por punto allí se va diciendo de sus edades, de su crecer en gracia y hermosura, en conocimiento, virtud y vida. Ese libro

\begin{abstract}
"digo que es una imagen compuesta por la mano de Dios, en que se nos muestran por señales y semejanzas visibles, y muy familiares al hombre, las dulzuras que entre estos dos esposos pasan, y las diferencias de ellas conforme a los tres estados $y$ edades diferentes que he dicho. Porque en la primera parte del libro, que es hasta cuasi la mitad del segundo capitulo, dice Dios lo que hace significación de las condiciones de esta su Esposa en aquel su estado primero de naturaleza, y la manera de los amores que le hizo entonces su Esposo. Y, desde aquel lugar, que es donde se dice en el segundo capítulo: 'Veis, mi Amado me habla y dice: levántate, y apresúrate y ven', hasta el capítulo quinto, adonde torna a decir: 'Yo duermo y mi corazón vela', se pone lo que pertenece a la edad de la ley. Mas desde alli hasta el fin, todo cuanto entre aquí estos dos se platica es imagen de las dulzuras de amor que hace Cristo a su Esposa en aqueste postrero estado de gracia" 122 .
\end{abstract}

Vengamos ya al Cantar de los Cantares. En ese poema veia la cumbre de la inspiración literaria y el secreto concentrado de los misterios de Dios sobre la humanidad, proféticamente anunciados. Tras la letra de los amores de Salomón con la hija del rey de Egipto se esconde el eśpíritu que se refiere al crecimiento por "grado de amor" de la vida divina en los justos y en la Iglesia ${ }^{223}$. El libro encubre, pues, los ocultos designios de Dios sobre el hombre y la historia. Como en nigún otro texto, se echa de ver en él que: aliud dicitur, et aliud significatur ${ }^{124}$. Los amores y requiebros que en el poema se describen plane, significan figurate et allegorice la unión del

121. NC, "Esposo", 657.

122. NC, "Esposo", 657-658.

123. In Canticum Canticorum Salomonis Expositio: Opera, II, 84; 87; 92 ; 96; 98. De cómo es usual estilo de Dios en la Escritura el hablar con nosotros "como hombre a otros hombres", diciéndonos "sus bienes espirituales y altos con palabras y figuras de cosas corporales"; cf. NC, "Brazo de Dios", 538.

124. In Canticum Canticorum Salomonis Expositio: Opera, II, 86. 
Cristo con el justo y con su Iglesia. De modo que aliud dicatur, aliud intelligatur ${ }^{125}$.

El desentrañamiento de ese texto puede decirse que ocupó a fray Luis de por vida. En 1561 hace la traducción y redacta el comentario en castellano con destino a Isabel de Osorio. En 1571 se ocupa en su traducción al latín, que publica, junto con la declaración del salmo XXVI, en 1580. Aparece la segunda edición en 1582. La tercera de 1589 incluye la "comentario triple". El tercero de ellos es el que se refiere a la unión de Cristo con la Iglesia, que se realiza por edades dando cumplimiento a su historia. Acomete esa declaración tercera con recelos y sólo a instancia de presiones amistosas ${ }^{126}$.

Ya la unión de Cristo con el alma y el sucesivo crecimiento en ésta de la gracia es figura de la creciente unión, de edad en edad, de Cristo con la Iglesia. Al amor de Dios asciende el alma por tres grados de los que han venido ocupándose los autores espirituales. Estos grados corresponden al de los principiantes, proficientes y perfectos. Corresponden a otros tantos géneros de vida. Cada uno de ellos está descrito en partes definidas del Cantar. Fray Luis señala una vez más la extensión precisa del texto que se refiere a cada uno ${ }^{127}$. Interesa señalar cómo se entiende ahí la vida en proceso dinámico abierto a un crecimiento escatológicamente orientado.

125. In Canticum Canticorum Salomonis Expositio: Opera, II 83; $90 ; 103$.

126. In Canticum Canticorum Salomonis Expositio: Opera, II, 82. Ese mismo asunto fue objeto de lectura de uno de sus cursos (1585-1586). La comprensión y exposición de ese texto no la tiene por fácil, antes las cree laboriosas y sujetás a malcomprensiones. Pero era parte de su genio el acometer obras que entrañassen dificultad; no le seducía en cambio andar por los caminos trillados e insistir en los tópicos convencionales de la teología. No hay que olvidar que de su ocupación con el Cantar de los Cantares se derivaron, en buena medida, las duras pruebas de su proceso y cárcel.

127. In Canticum Canticorum Salomonis Expositio: Opera II, 42: "Cum in hoc animi ad Deum amoris ascensu sint tres gradus, e quorum infimo per medium ad supremum pervenire quisque potest, et vero multi perveniunt: quod gradus viri sancti, et horum amorum periti, et distinxerunt olim, et notaverunt propriis nominibus: nam qui in infimo gradu esset, eum incipientem appellarunt: cum idem ad ulteriora profecit, proficientium gradum tenere dixerunt: ubi autem ad supremum evasit, iam perfectum ipsum nominantes perfectorum in gradu collocarunt. Igitur cum haec ita sint, dico ad hanc tripartitam vitae, atque graduum divisionem, hoc omne carmen a Salomone accommodatum esse : et illos tres gradus, quamvis nominibus eorum tacitis, re tamen ipsa atque vi positos esse ab eo in hoc carmine affirmo, Deum amare incipientis affectus, atque voces describuntur, a cap. I usque ad capitis II partem illam: "Vox dilecti mei". $\mathrm{Ab}$ eo loco ad illum capitis quinti, ubi eadem verba, scilicet: "Vox dilecti mei", repetuntur, proficientis in amore tota ratio declaratur. Reliqua vero carminis ad finem usque, perfectorum, in amore propria plane sunt. Itaque his tribus in locis, trina sit pulchritudinis sponsae commemoratio: eaque laudibus ce- 
Trasladado el interés en la tertia explanatio a la vida de la Iglesia, nos muestra su historia sucediéndose de nuevo por tres edades. Cada una de ellas revela un aspecto del modo cómo Cristo sustenta, auxilia, consuela, protege, variamente, según las circunstancias, a su Iglesia (pp. 175-176). Todas ellas marcan los grados por los que progresa su amor: "omnis enim Ecclesiae progressus in eo positus est, ut fiat similis Christo, ad quem illa, quanto magis similitudine accesserit, tanto magis proficiet (p. 270). Que son otros tantos grados de unión del hombre con Dios, sometiendo éste a El su mente: etenim Deus quo magis ipsi se submittit humana mens, eo magis intime se in eam insinuat, propriorque illi fit (p. 290). Los pasos de esta unión por crecimiento en el amor representan los de redención de la esclavitud, como se simboliza en el Exodo israelita del dominio y trabajos padecidos en Egipto, camino de la libertad, aunque no sin las estrecheces y peligros del desierto, hacia la patria prometida (pp. 178, 179, 181, 184).

Esa peregrinación es la que se describe, poetico more, en el Cantar. Toda ella, que es todo el tiempo de vida de la Iglesia, se deja comprender en "tres edades", a cada una de las cuales, a su vez, se refieren las conocidas partes del poema: la primera, desde el principio hasta el verso octavo del capítulo segundo; la segunda, desde ese lugar hasta el verso tercero del capítulo quinto; desde ahí hasta el final la tercera.

"Entiendo que la historia entera de la Iglesia militante, que se refiere al mutuo amor entre ella y Cristo, se contiene y explica en ese escrito, cosa que tengo por cierta. Lo cual para mostrarlo sin error ni confusión conviene advertir que la edad y duración de la Iglesia puede dividirse en tres tiempos: el primero de naturaleza, el segundo de ley y el tercero de gracia. El primero se extiende desde Adán hasta la promulgación de la ley. El segundo alcanza desde Moisés hasta Cristo. El tercero, desde Cristo hasta el fin de los siglos" (p. 116) ${ }^{128}$.

lebratur ter...". (Cf. también pp. 174; 195; 292-293; 294-296). Como las referencias a la Exposición del Cantar de los Cantares se repiten en los puntos siguientes, se incluyen las páginas en el mismo texto.

128. "Nam profecto dum omnis huius Carminis partes considero, et cura adhibita alias cum aliis confero, mihi videor videre elucentem in eo duarum maximarum rerum duas imagines. Unam amoris eius, quo Ecclesia ab exordio usque ad finem mundi Deus amat; amaturaque est. Alteram eius charitatis, quam Deus per omne id tempus exhibuit, atque exhibiturus Ecclesiae. Quare iudico omnium qui unquam fuerunt futurive sunt bonorum, ac fidelium hominum rationes, quod pertinet ad pietatem eorum erga Christum, et ad gradum quem in 
Cada uno de esos tiempos corresponde a un estado de perfección. Paralela a la perfección de los tres estados por los que progresa en unión con Dios el alma. El libro se divide claramente en esas tres partes; de modo que explicándolas se explican "las tres edades de la Iglesia", edades de crecimiento en el amor: huius igitur totius rationis, atque progressus imago, in hoc libro mirifice descripta extat (p. 117). Capítulo por capitulo, de los ocho del carmen místico, nos muestra en la tertia explanatio la secreta transformación de la historia bajo la acción divina que todo lo administra conforme a un orden providencial, ya que divino nutu cuncta regi (p. 204).

Considerando aparte la evangelica Ecclesia, es decir, la que corre desde Cristo hasta el final de los tiempos, interpreta sus pasos según modelo donde se suceden las edades de oro, de marfil y de mármol, en un discurso de envejecimiento y deterioro (pp. 315, 380). Mas para asistir a la recuperación última, que tendrá lugar cuando la fe se extienda por todo el mundo, los judíos se conviertan y los justos se purifiquen con las pruebas de los días postrime$\operatorname{ros}{ }^{129}$.

Los periodos de esas tres edades de la "Iglesia evangélica" se establecen así el primero, desde los Apóstoles hasta Constantino rey de romanos; la segunda, desde la época de Constantino hasta la del pontífice Gregorio; la tercera dura desde entonces hasta nosotros. De la primera a la segunda nescio quomodo rebus in deteterius abire insipientibus - remite el impulso de la piedad. Ello se acentúa en la tercera, en la que la "república cristiana", por una parte ve arrebatadas de su seno provincias enteras, decreciendo por otro el fervor de la sencilla piedad. Pero en la cuarta edad los hombres se conventirán a la virtud, reformándose sus costumbres hasta recuperar la pureza de los orígenes.

Leyendo la exposición al Cantar se confirma uno en la idea de que fray Luis no se hacía ilusiones sobre el estado de vigor de la Iglesia en su tiempo. Repetidamente vuelve a su consideración lá imagen de los primitivos tiempos de fervor, en los siglos de los Apóstoles y los Padres y Doctores, para ver en la historia siguiente

virtute tenuerunt, tradi in hoc carmine, hoc est, censeo in hoc libro explicari quo pacto se Christus erga suam Ecclesiam geratur, ab eo tempore, quando illa in terris primum esse coepit, et eam sibi desponsavit ipse, ad id usque tempus, quando eamdem in coelum sublatan accipiet uxorem. Itaque totam Ecclesiae militantis historiam...": (Opera, II, 116). 175.

129. Opera, II, 451, 457; In Abdiam prophetam explanatio: Opera, III, 172- 
un alejamiento cada vez mayor de aquellos orígenes que siente como ejemplares ${ }^{130}$. Como aspera et aerumnosa tempora ve su propia edad (p. 192) ${ }^{131}$. Los fieles toman cara de pseudocristianos, cubriéndose con el nombre de Cristo toda suerte de bajezas humanas e intereses mundanos (pp. 457-459). Los obispos y pastores, llamados a estar constituidos en ejemplo, son con sus costumbres ocasión de ruina (p. 302). Los gobernantes convierten los medios que tienen en su mano, y que debieran ordenarse al bien común de los hombres, en recursos de tiranía.

"Lo que podría probarse con muchos ejemplos de los que no en escasa copia nos ofrece nuestra edad. Sed ea omittam, quoniam commemorari sine aliquorum offensione non possunt" (p. 303).

Las páginas finales de la declaración, más bien que las que corresponden al canto de las obras de Dios en triunfo, parecen significar su fracaso, aunque se cierren invocando a Cristo para que se muestre desde el cielo y salga por su honor poniendo remedio a tantos males (p. 462). En todo caso, la edad cuarta de la Iglesia será de triunfo, y todo ello está significado en el Cantar. Ecclesiae igitur ab ipsius exordio, id est, a mundi initio, per omnes eius aetates usque ad saeculi finem ducta, et in hoc carmine explicata ratio hac fine concluditur (p. 462).

Vemos, pues, que en la interpretación del texto de los Cantares

130. "...veteris illius Ecclesiae, quae ante mille annos felicissime floruit, saltim exempla respiciant": (Opera, II, 208); “...ut bonis et antiquis moribus suum animum ornent": (Opera, II, 458).

131. "Ego sane sic existimo, Christianae reipublicae antiquos mores ex eo potissimum tempore in deterius labi coepisse, cum divinarum litterarum, atque legunt imperiti homines cathedras Ecclesiae occuparunt. Una enim cum illis avaritia, una luxus, atque factus, una crudelitas et immanitas, aliaeque innumerae pestes, in christianos mores invectae Ecclesiam oppresserunt, oppressamque ita tenent, ut regressus ad salutem nullus fere sit reliquus; futurumque videatur, quod non parum multi pii, et sancti homines, non sine causa, atque argumento verentur, ut quemadmodum orientis populos, apud quos olim christiana disciplina vigebant, tenebris erroris involvi, illorum offensus peccatis Deus permisit: sic etiam nos, nostris irritatus culpis, abiiciat, sibique quaerat, atque provideat alios populos humiles, et ad sementem gratiae accipiendan, et ad fructum proferendum idoneos, ad quos simul cum fide Jesu Christi filii sui transferat a nobis ablatum coelestem regnum, et Spiritus Sancti charismata. Nam et hoc ipsum, iam ante mille annos timuit Augustinus; imo non tam timuit, quam praevidit futurum... In hos timores, malasque spes, et in has populi christiani ruinas incidimus ruendi initio facto ab iis, qui divinarum litterarum ignari, atque rudes, non omnis improba constingitur, ne se effundat, et coercetur cupiditas, veluti froenum, timor Dei...": (Opera, II, 209; cf. 302-303; 318-319; 461). 
se mezclan los diversos motivos de que hemos hecho mención anteriormente al enjuiciar la idea de fray Luis ante la historia. Domina el discurso la visión de la misma según el modelo abierto a edades sucesivas en crecimiento, en las que se viene de la esclavitud a la libertad, del temor a la esperanza, de la miseria a la felicidad (pp. 179-182). Ese discurso acabará en la edad más allá de las edades sujetas a las vicisitudes de los tiempos; es decir, en la edad de la gloria.

Con esa visión interfiere aquella otra en la que se introduce el modelo que consagra como ejemplares los orígenes, en relación con los cuales los tiempos posteriores se presentan como degeneraciones de las que remediará una nueva intervención del principio arquetipico.

El crecimiento abierto por edades en una historia que asume los tiempos en un designio salvífico se aplica a la Iglesia que existe desde el inicio del mundo, duradera hasta su final. Mientras que la edad de la "Iglesia evangélica" es vista según la imagen del sucesivo deterioro. Las dos direcciones, no obstante, confluyen en cuanto a la imagen final, ya que a nuestra edad de decadencia y miseria seguirá la de triunfo del evangelio, en la que se muestre en toda su virtud la fecundidad de la gracia.

Entretanto, esa doble óptica permite a fray Luis dar cuenta de unos tiempos intermedios que se resisten a dejarse incluir en el esquema unánime de un ascenso hacia el bien. Su propia vida encajaba mal en ese esquema. No todo lo que veía en torno suyo se componía obvia y abiertamente con unos tiempos de salvación ${ }^{132}$. Pero

132. Abundan los diagnósticos históricos poco optimistas en la obra de fray Luis; pero no espera uno encontrarse al final de la exposición al Cantar, cuando parece llegado el momento de ver producirse el reino de la luz, del bien y de la paz, tiradas como ésta: (se refiere a la expectativa del advenimiento de Cristo y se preocupa por el mísero estado de costumbres que reina en el pueblo cristiano) "quando videmus pietate eliminata, et omni antiquo more et disciplina deletis, tot vitiorum, et quae vitia semper commitantur, malorum agmina in Ecclesiam, non modo invasisse, sed domicilium in ea posuisse, consedisseque, ac penitus insinuasse se, et infudisse per eam universam, et in mores abiisse nostros, ita penitus ut, omni humana desperata ope, salutis et mutationis in melius, fere nulla reliqua sit spes praeter eam, quae posita est in Christi adventu, cuius illustratione adventus impietas est extinguenda. Nam, per Deum immortalem, quid mali abest, quod si adesset, nostra tempora misseriora efficere et calamitosiora posset? externus hostis; isque potentissimus, et infestissimus christiana regna devastat: nos inter nos colidimur intestinis dissidiis: de religionis doctrina orta dissensio, a parvis primum ducta initiis, ita crevi paulatim, ut innumerabiles populos, atque nationes $a b$ Ecclesiae corpore dividens, in errores induxerit perniciosos et impios. Quod porro syncerum adhuc, et ab errore doctrinae liberum ac fidei verae retinens, manet in Ecclesia, quod quam sit perexiguum sine gravi animi dolore memorare non possumus: ita est contaminatum omni peccatorum genere 
Dios escribe recto con trazos quebrados. Las almas mas allegadas a El son las sometidas a mayores pruebas, de lo que es ejemplo la figura de Job. En lo revuelto del negocio del hombre puso de manifiesto Dios la traza de su obra redentora. Así también en el desconcierto externo de las edades se oculta el designio místico de la salvación.

Hay un punto que todavía interesa subrayar. Puesto que para fray Luis la historia es profética, sus eventos van poniendo de manifiesto un invento de conjunto en el cual, latente y como en cifra, puede rastrearse lo que llega a ser patente y descifrado ${ }^{133}$. Las edades últimas de la Iglesia están prefiguradas en las primeras. Los acontecimientos decisivos ocurridos en un tiempo posterior estaban significados, aunque bajo figuras, en el tiempo anterior. Esto tiene lugar eminentemente en relación con el evento histórico que recapitula la historia, es decir, la venida de Cristo. Pero de alguna manera puede decirse lo mismo de todos los demás. Es sintomático a este respecto el modo de referirse fray Luis al descubrimiento de América, hecho de importancia htstórica indisqutible, máxime en su tiempo; también y sobre todo por la incidencia que tenía en relación con la vida de la Iglesia. Pues bien, en las diversas ocasiones que nuestro autor toca ese asunto lo entiende bajo luz profética. En las páginas finales del comentario al Cantar se refiere a él, refiriendo uno de sus versos al reciente nuevo mundo descubierto y su incorporación a la Iglesia: significatur hispanorum navigationibus reperti orbis, eiusque incolarum ad Christi fidem nuper facta conversio (p. 450). Y añade que esto se encuentra prenunciado en los profetas Isaías y Sofonías (pp. 450-453). Trata más por extenso esa misma cuestión en su comentario al profeta Abdías, afirmando:

atque corruptum: iis animi morbis laborat, tam exitialibus, tam immedicabilibus, nihil ut esse minus videamur, quam quod dicimur, et nominamur, christiani":: (Opera, II, 461).

133. "Est et hoc advertendum, proprium esse Litterarum sanctarum, ut narrandis, atque recensendis quibusdam gestis rebus, quae quomodo commemorantur evenisse, ita plane evenerunt, maiora quaedam et sublimiora alia; non quidem adhuc gesta, sed futuro gerenda tempore, is tamen quae gesta narrantur similia, significent, atque praedicent. Quae, ex unis rebus praeteritis et commemoratis, aliarum rerum post futurarum praedictio, allegoria rerum vocari non inepte solet his litteris propria, ab illaque distincta, quae duobus aut pluribus verbis translate positis, aeque perpetua metaphora efficitur, quae retorum est, et linguis communis omnibus": (In Abdiam: Opera, III, 29). "Hoc est in sensu histrico ab historia recedere. Imo non recedere ab historia, sed ipsam variare, hoc est, ex una earum, quae vati ad dicendum propositae sunt persona, aut gente, ad aliam personam aut gentem transilire... Nam historia verbis, cum propriis, tum translatis conscribitur": (In Abdiam: Opera, III, 35-36). 
ergo eam rem sine dubio inseruerunt suis scriptis prophetae. $\mathrm{Y}$ remite especialmente a Isaías ${ }^{134}$.

Podrá resultar fantástica semejante exégesis a la altura crítica en que hoy nos encontramos; pero no puede por menos de admitirse como reveladora. La historia era para fray Luis el libro abierto de los designios de Dios. Era entendida bajo la unidad de un propósito iluminando por dentro los tiempos y cumpliéndose a través de las edades, sacando de ella por pasos la plenitud de un sentido que recoge en discurso unánime y según un orden oculto la multiplicidad aparente de las gestas humanas.

Por lo que hace a la tercera de las proposiciones de las enunciadas al principio de estas páginas, dada la extensión que ha adquirido el desarrollo, parece oportuno dejarla como cuestión abierta, haciendo observar tan sólo lo siguiente: 1) La "historia exterior", desmemoriada o desesperanzada, no recibe de fray Luis más que despego; cuando se ocupa de ella es para describirla como lugar de confusión, escenario de la ruindad o malicia de los hombres. 2) Elige como tópicos de su reflexión motivos intemporales o purificados del contacto con el tiempo exterior, como ocurre en su obra poética; en los comentarios escriturísticos prefiere los que discurren sine historiae argumento, conforme observa al comienzo de su Explanación al Salmo 26. 3) Sin embargo, el status quaestionis de cada uno de sus escritos se argumenta de continuo en términos históricos, no conceptuales, y con datos tomados de la historia externa. 4) Sus tópicos de reflexión - sine historiae argumento- son siempre leídos y entendidos a la luz de un "sentido interno", siendo su pensar, en este orden, esencialmente histórico. 5) La historia que aparece es trasunto de la que se oculta; y, cuando se mira a esa luz, aquellas mismas cosas tras las que se afanan los hombres, y que, sustentadas en sí mismas, son lugar de desconcierto, que "el

134. In Abdiam prophetam explanatio: Opera, III. Recorriendo la historia del mundo, apenas puede encontrarse un hecho, nos dice, de la importancia del ocurrido en nuestra edad, "cum novus, et hoc Romano non minor, sed latior fortasse atque maior orbis, ab Hispanis, vastissimo enavigato mari, repertus est. Alias enim terras esse praeter eas, quas colebamus praesertim tam spatiosas atque latas nemo putabat, et ut suspicaretur aliquis, tamen incoli eas, et frequentari ab hominibus posse nemo credebat: maxime autem novum at admiratione dignum visum est, tan frequenter eas habitatas propter infinitam hominum, quos gignunt atque alunt multitudinem, tot saeculis latere potuisse, ipsosque earum incolas per tot annos in tantis iacuisse vitiorum tenebris ut vix tandem, lumini Evangelii, ut ad eas introire posse, aditum sit patefactum...": (Opera, III, 156158). 
vulgo vil adora", y precisamente porque lo adora, resultan pregnantes de nuevo y trascendente sentido, ordenándose en una historia de Dios, en la que al fin serán recapituladas, aunque en el intermedio discurran como olvidadas de ello. 6) En suma, historia verbis, cum propriis, tum translatis conscribitur. La escena del mundo es un palimpsesto, en el que un discurso se muestra en signos claros a la vista y otro corre por debajo, siendo éste último el que contiene enseñanza venerable borrada por incuria, siendo así que es la clave de intelección del primero: uno nomine, duae gentes. El mismo nombre mienta estos dos linajes de gentes, en un caso traslaticia, en otro propiamente. 7) La vida humana se entenderá en concierto cuando se interprete el discurso traslaticio por el sentido del propio. Pero esto es lo que echan en olvido los hombres, de donde resulta que los dos linajes de gentes se dividen en "dos siglos". Son pocos los sabios a la escucha de los secretos designios de Dios. Los más de entre los hombres dan por propio el discurso traslaticio y sucumben al "mundanal ruido". Para pertenecer a los primeros hay que estar versado en los dichos y escritos de vates y profetas ¿Quiénes son varones? Qui diligenter in vatum scriptis versatus erit; qui, quae sit vaticinationum ratio atque vis, satis intelliget; qui sciet multa atque varia, et cum locis diversa, tum divisa temporibus vatum cogitationibus uno et eodem tempore subiici; qui denique eorum dicendi morem satis calluerit (Opera, III, p. 36). Pero todo esto sonará a artificioso a quienes sólo saben moverse entre cosas claras y tangibles, entre los hechos de los hombres, donde si algo se oculta son sus insidiosas intenciones. La Iglesia de Dios ofrece el ejemplo a seguir a los que de corazón están con ella. También ofrece el mundo a los suyos ese ejemplo: nos exequamur institutum argumentum, illos autem sua adamare sinamus (ibid.).

Saturnino Alvarez Turienzo, OSA. Universidad Pontificia SALAMANCA 